\title{
Constitutional Limitations on the
}

\section{Naturalization Power}

According to international law, each sovereign nation has, in the absence of international agreement, absolute discretion in controlling aliens within its borders. ${ }^{1}$ Similarly, international law imposes no restrictions on sovereign power in granting citizenship to aliens. There is no requirement that a state provide for naturalization; and, if it does make provision, it is free to establish any conditions precedent.

Under the United States Constitution, of course, there are limits on government power. In a "non-naturalization context," a resident alien does, generally, have constitutional rights. ${ }^{2}$ However, with respect to

1. Each nation, under international law, possesses inherent power to bar entry to aliens, as well as power to restrict their actions or expel them after entry is granted. See 1 C.C. Hyde, International Law 217 (2d ed. 1945); H. Inuterpacitr, an internationisl BLL of the Rights of MAN 124 (1945); E.M. Borchard, Diplometic Protection of CrtIZENS ABRoad 46 (1915). See also, A.V. Freearan, The Internitionde Responsiniluty of STATES FOR DENIAL OF JUSTICE 227 (1936).

2. The rights which resident aliens possess in non-naturalization contexts include those guaranteed by the First and Fifth Amendments. The First Amendment is vritten in absoIute terms; there is no indication in the text that its guarantees of free expression and association apply only to citizens. (It must be assumed that the framers of the Constitution and the Bill of Rights did not want to limit the protection of the First Amendment to citizens, since when they did so intend they were explicit. See Privileges and Immunities Clause of art. $4, \S 2$ and Fourteenth Amendment $\$ 1$.) In addition, the "basic theory of freedom of expression would seem clearly to preclude any special restriction upon freedom of expression by aliens." T. I. EAIERson, TOWard a GENERAC TIIEORY OF tHE Finst Adrendarent 101 (1963). First, free expression is essential to the dignity and personal fulfillment of free men, $i d$. at pp. 5-11; and there is no apparent reason why resident aliens, who constitute a significant segment of the population, should be denied such benefits. Second, free speech is essential to the successful functioning of representative government. Sce B. Cardozo, The Paradoxes of Legal Science 104-05 (1928); Abrams v. United States, 250 US. 616,630 (1919) (Holmes, J., dissenting). Elected officials must be informed of the desires of all who will be subject to the rules which they make, whether or not those subjected are voters. To hold the contrary would be to assume that lawmakers are uninterested in the welfare of non-voters, who constitute over half the population. And third, resident aliens must have the right of free expression as a corollary of the first amendment rights of citizens. To restrict the ability of aliens to communicate would be to limit the varicty of opinions and associations to which citizens have access. See Red Lion Broadasting Co. v. FCC, 395 U.S. 367 (1969); Lamont v. Postmaster General, 381 US. 301, 307 (1965); Note, Operiing the Floodgates to Dissident Aliens, 6 HARv. Crv. RuGHTs-Crv. Lm. L. REv. 141 (1970).

The Due Process Clause of the Fifth Amendment protects "persons," not merely "citizens." See Bridges v. Wixon, 326 U.S. 135, 161 (1945) (concurring opinion); United States v. Pink, 315 U.S. 203, 228 (1942); Wong Wing v. United States, I63 U.S. 228, 242, 249 (Field, J., concurring in part and dissenting in part) (1696); Hee Chan Y. Pilliod, 178 F. Supp. 793, 797 (N.D. Ill. 1959). In non-alien-oriented contexts, that is, in contexts other than exclusion, deportation, or naturalization proceedings, it has long been recognized that resident aliens are "persons" within the context of that clause, and are guar- 
naturalization statutes, ${ }^{3}$ constitutional limitations do not exist. Except for a procedural due process requirement, the courts have adopted the international law concept of unfettered sovereign power. As the Supreme Court put it in 1931:

Naturalization is a privilege, to be given, qualified, or withheld as Congress may determine, and which the alien may claim as of right only upon compliance with the terms which Congress imposes. ${ }^{4}$

\section{That principle is controlling today.}

This Note will argue that normal standards of constitutional adjudication should apply in naturalization cases. It will evaluate current statutory provisions and administrative practices in light of those standards.

anteed both procedural and "substantive" rights. Procedurally, aliens are entitled to the same fifth amendment safeguards as are citizens. And substantively, resident alleng are protected by the Fifth Amendment from government action which is "arbitrary and ato pricious"-action which is not properly related to the furtherance of a legitimate governmental objective. $C f$. Takahashî v. Fish and Game Commission, 334 U.S. 410, 421 (1948); Di Pasquale v. Karnuth, 158 F.2d 878 (2d Cir. 1947). The substantive due process rights of aliens include the requirements of the Equal Protection Clause. Cf. Bolling v. Sharpe, 347 U.S. 497, 500 (1954); Hurd v. Hodge, 334 U.S. 24, 35 (1948).

3. Naturalization statutes are enacted pursuant to Article I, Section 8, which provides that Congress has power "[t]0 establish an uniform Rule of Naturalization." No uniform rule of naturalization existed prior to the Constitution. One State conferred citizenship whenever a foreigner landed on its shores. Other states required waiting periods of varying lengths. The lack of national uniformity imposed hardships; a person might lose his citizenship merely by moving to another state. F. VAN DYNE, A TREATISE ON TIIE LAY OF NATURALIzATION OF THE UNITED STATES 6 (1907). The framers of the Constitution realized the importance of relieving this confused condition. See James Madison in 3 Trut RECORDS OF THE FEDERAL CONVENTION of 1787 at 548 (Revised ed. M. Farrand cd. 1966).

4. United States v. Macintosh, 283 U.S. 605, 615 (1931). See Fong Yue Ting v. United States, 149 U.S. 698, 707-708 (1893). In re Warkentin, 93 F.2d 42, 43 (7th Cir. 1937), cert. denied, 304 U.S.'563 (1988); United States v. Tapolcsanyi, 40 F.2d 255, 257 (3rd Cir., 1980); In re Taran, 52 F. Supp. 535, 539 (D. Minn. 1943).

Asserting that there is no "right" to be naturalized, courts have concluded that Congresg is not obligated to grant citizenship to any alien. City of Minneapolis v. Reum, 56 F. 676, 577 (8th Cir. 1893); United States v. Zgrebec, 38 F. Supp. 127, 129 (E.D. Mich. 1941). And, assuming that citizenship can be withheld from all aliens, courts implicitly reason that: (1) Congress has power to impose any conditions precedent because the power to with hold must necessarily include the lesser power to grant only upon fulfillment of conditiony, and (2) since there is no right to citizenship, the burden of proof is on the petitioner to establish that he has met all statutory requirements.

Evidently feeling a tension between the concept of unfettered sovercign power over naturalization and traditional constitutional doctrines, courts have narrowly construcd naturalization statutes. In interpreting general or vague statutory requirements, judgcs have refused to infer a congressional intent which is inconsistent with their views of American history and concepts of justice. Girouard v. United States, 828 U.S. 61, 64 (1946). However, when the words of the statute are clear and unambiguous, courts have con: sistently viewed their function as merely determining whether a particular individual has met a given statutory requirement. Schneiderman v. United States, 320 U.S. 118, 132 (1943); United States v. Macintosh, 283 U.S. 605, 627 (1931) (Hughes, C. J., dissenting); Petition of $\mathrm{O}-\mathrm{N}-233$ F. Supp. 504, 509-10 (S.D.N.Y. 1964). As a result, holdings of naturalization cases have almost exclusively involved construction and application of statutory provisions rather than a determination of their constitutionality. See Note, Constitztional Limitations on the Power of Congress to Confer Citizenship by Naturalization, 50 IowA L. REv. 1093, 1096 (1965) [hereinafter cited as IowA]. 


\section{The Doctrine of Unfettered Congressional Power and the Naturalization Process}

The naturalization process begins when a non-resident alien achieves the status of resident alien by entering the United States on an immigration visa ${ }^{5}$ which entitles him to live permanently within the country. ${ }^{\circ}$ After five years in residence, a resident alien can file a naturalization petition in a United States District Court. ${ }^{7}$ Subsequent to the filing, but prior to court action, a special inquiry officer of the Immigration and Naturalization Service (INS) conducts an investigation to determine whether the government will oppose the petition. ${ }^{8}$ The final hearing on the petition is held in open court. ${ }^{9}$

The doctrine of unfettered congressional power over naturalization affects this process in several ways. First, a resident alien who wants to become a citizen, will, if he is aware of the conditions in the naturalization statute, ${ }^{10}$ act during the five year "probationary period" prior to filing his petition only in ways which will not jeopardize his chances for naturalization under the statute as written. He will be unlikely to violate a condition with the thought of later challenging its constitutional validity.

Second, a resident alien who is aware that he is disqualified by the statute as written will probably not file a petition. He will be unlikely to incur the expenses of litigation after his lawyer informs him that, whatever the statutory conditions may be, Congress had power to enact

5. The Constitution makes no express provision for control over immigration. Nevertheless, Congressional control of immigration is firmly established. The power to exclude aliens is "inherent in sovereignty." Nishimura Ekiu v. United States, 142 U.S. 651, 659 (1892). The power to deport is regarded as a corollary of the power to exclude as well as a power incident to sovereignty. Fong Yue Ting Y. U.S., 149 U.S. 698, 707 (1S93). See Note, Residence Requirements After Shapiro v. Thompson, 70 Colus. L. REv., 134, 143 n. 57 (1970).

6. Aliens entering on nonimmigrant visas, 8 U.S.C. 8 1184(a)(1964), an remain only temporarily and are not eligible for naturalization. 8 U.S.C. $\$ 1427(a)(1)(1964)$.

7. 8 U.S.C. \& 1427(a)(1)(1964). Before the petition will be processed, the alien must establish his lawful entrance and residence in this country-in short, that he is not sub. ject to deportation. 8 U.S.C. $\$ 1429$ (Supp. V, 1970), amending 8 U.S.C. \& 1429 (19G4).

8. 8 U.S.C. $\$ \S 1446,1447$ (d) (1964). During the course of the investigation, the officer is allowed to question the applicant.

9. 8 U.S.C. \& 1447 (a)(1964).

10. Every naturalization statute has contained conditions which must be satisfied by the applicant for citizenship. For a discussion of naturalization Iegislation, see Developments in the Law: Immigration and Nationality, 66 HARv. I. REv. 643 (1953). Two general requirements, presently compiled in 8 U.S.C. \$ 1427(a)(1964), are usually included: Attachment and allegiance to the Constitution and the nation, and good moral character during a specified period prior to filing the petition. Past statutes have contained specific conditions denying naturalization to Negroes, I Stat. 103 (1790); Orientals, Act of Miray 6, 1882 , ch. 126, \& 1, 22 Stat. 58 (1882); and certain classes of women, 34 Stat. 1228 (I907). The present statute, passed in 1952 , abolishes the old restrictions based on race, ser and national origin. 8 U.S.C. \& 1422 (1964). However the present law includes many other specific limitations which will be discussed throughout the Note. 
them. Further, of those resident aliens who do file petitions, very few proceed to the courtroom phase after an unfavorable report by the INS special inquiry officer. In the year ending June 30, 1969, only 152 of over 2040 unsuccessful petitions (or 7.4\%) were rejected by a judge. ${ }^{11}$ In terms of disappointed petitioners, therefore, the crucial part of the process is the investigation and recommendation of the special inquiry officer.

This wide administrative discretion is apparently fostered by the doctrine of unfettered congressional power. As an example of this effect, several lawyers prominent in naturalization practice ${ }^{12}$ cited INS administration of the statute's "good moral character" requirement. ${ }^{13}$ They reported that special inquiry officers frequently conclude that applicants lack the requisite moral character if they arc, for example, unemployed, receiving welfare benefits, or suffering from a venereal disease. Such determinations, these lawyers explained, would likely be overturned if taken to court-not because Congress is powerless to establish such requirements, but because many judges would hold that such conditions are not necessarily indicative of poor moral character and hence not included under the relevant statutory provision. However, petitioners' lawyers often decide against taking such cases to court, because INS officials have told them that, if administrittive determinations that certain statuses are indicative of poor moral character are overturned by the courts, the Bureau will ask Congress to exercise its "unfettered" power and write explicit statutory restrictions. ${ }^{14}$ Rather than engage in protracted litigation which, in the long run, would likely result in congressional action damaging the interests

11. The statistics cited throughout this Note were compiled by the American Council for Nationalities Service in Naturalization Statistics for 1969, 47 INTERHETER RELIAS1'S 166-173 (No. 25, July 9, 1970).

12. Interviews were conducted with lawyers specializing in deportation and naturaliza. tion law, and prominent in the following organizations: New York Legal Aid Socicty, American Civil Liberties Union, American Council for Nationalities Service, and American Committee for the Protection of the Foreign Born. By agreement, they will not be identified.

These interviews were not an attempt to poll a "statistically valicl" cross-section of naturalization lawyers, but rather an effort to learn the views of several lawyers promincut in the field.

13. See note 10 supra.

14. The threat is not a hollow one, as is demonstrated by the Immigration and Nationality Act of 1952, presently in effect. Prior to the enactment of that statute, some courts had overruled the INS and held that adultery per se was not sufficiently indicative of poor moral character to warrant denial of naturalization, Petition of Rudder, 159 $\mathrm{F} .2 \mathrm{~d}$ 695, 698 (2d Cir. 1947), cited in Petition of $\mathrm{O}-\mathrm{N}-$, 283 F. Supp. 504, 506 (S.D.N.Y. 1961), and that extenuating circumstances should be considered. Congress responded with an explicit provision in the 1952 Act denying naturalization to adulterers per se, sec 8 U.S.C. $1101(f)(2)$, and that provision has been enforced. See 233 F. Supp. at 506.07, 509-10, 509.10 and cases cited at 507; cf. Zacharias v. Shaughnessy, 221 F.2d 578, 579.80 (2d Cir. 1955). 
of resident aliens in general, these lawyers advise their clients to withdraw their petitions, and to file new ones five years after the termination of the disqualifying condition. ${ }^{16}$ This practice must at least partly explain why, of the 571 petitions which failed on moral character grounds in the year ending June 30,1969 , only thirteen $(2.3 \%$ ) were taken to court.

In sum, the doctrine of unfettered power affects the naturalization process not only through unchallenged statutory requirements, but also through the power which the threat of future legislative action enables administrative officials to wield.

\section{The Case Against Unfettered Power}

To understand why the doctrine of unfettered power should be abandoned, and normal standards of constitutional adjudication applied in naturalization cases, it is necessary, first, to consider the anomalous character of this doctrine in the American consitutional system, and, second, to evaluate the rationales for unfettered power over naturalization.

\section{A. Constitutional Text and Governmental Structure: An Anomaly}

The Constitution grants powers to the national government and rights to individuals. A cardinal principle of constitutional interpretation is that neither the powers nor the rights are absolute ${ }^{10}$-neither the government nor the individual automatically prevails. Instend, courts struggle to find the proper accommodation between competing interests. 17 Under a concept of unfettered power, however, courts do not engage in a balancing process; the government automatically prevails. Individual interests, no matter how important, can be abridged by legislative action, without a consideration of the substantiality of the government interests furthered.

All the other powers enumerated in Article I, Section 8, in which the naturalization power is located, have been interpreted in accordance with the principle of non-absoluteness. ${ }^{18}$ Since there is no indication in the constitutional text that the naturalization power is unique, it would

15. Under the statute, only the five years immediately preceding the filing of a petition can be considered in determining moral character. 8 U.S.C. \& 1427(a)(1964).

16. See Niemotko v. Maryland, 840 U.S. 268, 273 (1951) (Frankfurter, J., concurring).

17. Even when the government interest prevails, the fact that an "accommodation": is made indicates that the individual interest is given some veight; it imposes some limit on the power of government to act.

18. See Iowa, supra note 4, 2t 1099. 
seem-simply as a matter of consistency in textual interpretation-that it should be similarly interpreted.

More important than an inconsistency in textual interpretation is that the doctrine of unfettered power over naturalization is inconsistent with the principles of the governmental system created by the Constitution. ${ }^{19}$ One basic purpose of the constitutional system of limited powers is the preservation of individual freedoms. That purpose requires that there be no absolute governmental power. Otherwise, the framers' entire design could be frustrated, for the exercise of one unlimited power could destroy the rights which the carefully constructed limitations on the others were intended to preserve..$^{20}$

\section{B. The Inadequacy of the Rationales for Unfettered Power}

Three reasons might be advanced to justify the anomaly of unfettered congressional power over naturalization. The first is that it is a necessary corollary of Congress' unfettered power to deny an alien initial entrance into the nation..$^{21}$ The second reason is that the status of citizenship is "vitally important," since it defines the relation between man and state. ${ }^{22}$ And the third is that, since naturalization policies affect the nation's foreign relations, the branches of government with responsibility for diplomacy must have absolute discretion in formulating those policies. ${ }^{23}$

\section{Corollary of the Power to Exclude}

In Fong Yue Ting v. United States, the Supreme Court asserted that the national government has absolute power to exclude all non-

19. As Professor Charles Black has argued, Structure and Renationsint in Constiru. TIONAL LAW (1969), the Constitution can be read as a structural blucprint for a govern. mental system as well as the source of specific rules. Doctrines and laws can be analyzed in terms of their congruence with the system's structure as well as their conformity to the specific rules. Since the existence of an unlimited congressional power is antithetical to a structure of limited government, one should not be presumed from the mere inclu. sion of a power in article I, section 8. See IowA, supra note 4, at 1098.9.

20. Limitations on government power might be viewed in two ways, One theory might construct limitations in the abstract. That is, even in the absence of injury to specific individuals, government would be prohibited from acting in certain ways. Even though such a theory is arguably appropriate with respect to various constitutional provisions, e.g., the Establishment Clause, it is clear that under the American system fimitationg can be enforced against government only when individual interests are adversely affected. Cf. Flast v. Cohen, 392 U.S. 83 (1968). Putting aside such abstract notions of limitations on government power in the absence of persons with constitutionally protected interests which are affected sufficiently to confer standing to seek judicial redress, it is clear that, in a system in which individual rights are protected by limitations on governmental powers, no power should be deemed unfettered when its exercise impinges directly on protected rights.

21. Fong Yue Ting v. United States, 149 U.S. 698, 713 (1893).

22. See IowA, supra note 4, at 1097 n. 22.

23. Lapides v. Clark, 176 F.2d 619, 621 (D.C. Cir. 1949), cert. den. 338 U.S. 888 (1949). 
resident aliens, or to admit them "only in such cases and upon such conditions as it may see fit to prescribe," 24 and further that "[ $t]$ he right of a nation to expel or deport [resident aliens, which obviously entails the right to deny them naturalization] ... rests upon the same grounds, and is as absolute and unqualified, as the right to prohibit and prevent their entrance into the country."25 However, even if the power to exclude is unfettered, ${ }^{26}$ it seems clear that the powers to deport and to deny naturalization are distinguishable from it. The basic justification for an absolute power to exclude, as the Court in Fong Yue Ting seemed to recognize, is the international law concept of territoriality ${ }^{27}$ -a state's domestic law has no effect outside its borders, except as it relates to its own citizens..$^{28}$ Since the Constitution, like every other American law, is subject to this geographic limitation, potential immigrants who, at least in the eyes of the law, remain outside American borders, ${ }^{29}$ cannot claim rights under the American Constitution. ${ }^{30}$ Under the doctrine of territoriality, in short, aliens seeking initial entry may be entitled only to those "rights" which Congress has granted them..$^{31}$

The concept of territoriality, however, has no application to deportation and naturalization proceedings, which concern resident aliens, ${ }^{32}$ and take place wholly within the jurisdiction of the United States. The Constitution's geographic limitations, therefore, are not controlling. Thus, even if the power to exclude is deemed unfettered, it does not follow that the power over naturalization must be.

24. 149 U.S. at 705.

25. Id. at 707. [Emphasis added.]

26. But see Note, Opening the Floodgates to Dissident Aliens, 6 Harv. Crv. Ruarrs.Crv. LBB. L. REv. 141 (1970) arguing that an alien's entry may be required to enforce a citizen's right to hear. See also, Mandel v. Mitchell, 39 U.S.L.W. 2531 (E.D.N.Y., Mfarch 30, 1971).

27. 149 U.S. at 706. See dissent of Justice Brewer, id. at 738.

28. See, Craig, Application of the Trading With the Enemy Act to Foreign Corporations owned by Americans: Reflections on Fruhoub v. Mfassardy, 83 Hunv. L. REv. 577, 586 (1970). United States v. Rodriquez, 182 F. Supp. 479, 488 (S.D. Calif., 1960); American Banana Co. v. United Fruit Co., 213 U.S. 347, 356.57 (1909); The Apollon, 22 U.S. $(9$ Wheat.) 362, 370 (1824).

29. Often, the alien is outside American territory only by legal fiction. For cxample, aliens entering by the port of New York are restricted to Ellis Island until the question of their right to enter is ruled upon. Clearly, Ellis Island is part of American territory. The fiction allows the alien to disembark while his entrance is considered.

30. But see note 28 supra.

31. See Knauff v. Shaughnessy, 338 U.S. 537, 544 (1950); Ludecke v. Watkins, 335 U.S. I60, 171-72 (1948); Nishimura Ekiu v. United States, 142 U.S. 65I, 659.60 (1892).

32. Kwong Hai Chew v. Colding, 344 U.S. 590 (1953); Yick To v. Hopkins, 118 U.S. 356, 369 (1886); Carmichael v. Delaney, 170 F.2d 239, 243 (9th Cir. 1948); United States ex rel. Tom We Shang v. Murf, 176 F. Supp. 253, 256.57 (S.D.N.Y. 1959). For a clear example of the difference between exclusion and deportation, compare $\mathrm{Ng}$ Fung Ho v. White, 259 U.S. 276 (1922), with United States v. Ju Toy, 198 U.S. 253 (1905). 


\section{The "Vital Importance" of Citizenship}

It has been suggested that some courts, viewing unfettered porwer over naturalization as implicit in the concept of national "sovereignty," have evinced a belief that "a sovereign nation has such a vital interest in citizenship that the system of constitutional government underlying the nation can be disregarded when Congress exercises the naturalization power." ${ }^{33}$ An analysis of the importance of naturalization to the government $t^{34}$ must focus on the government interest in preventing the change in its relationship to the individual.

The grant of citizenship alters the power and obligations of the government with respect to the individual in three ways: 1) the government must afford the individual diplomatic protection when he travels abroad; 2) the government loses the ability to deport the individual; and 3) the individual becomes entitled to vote and hold public office.

The government interest in preventing the first two of these changes in the individual-government relationship can be translated into the interest in avoiding expense. First, the requirement that the government afford naturalized citizens diplomatic protection entails administrative costs in issuing a passport and affording access to American consuls abroad. ${ }^{35}$ Second, the power to deport, which the government loses upon naturalization, ${ }^{36}$ might be exercised in two types of situations. First, the government might deport a person who had performed acts detrimental to the public welfare, such as criminal acts. Deportation of such persons would serve both to deter the general class of deportable persons from committing such acts and to ensure that those who did would not repeat the offense within the jurisdiction. However, assuming that an act is detrimental to the public welfare, it would be (or could presumably be made) a crime; substantially the same two func-

39. Iowa, stepra note 4, at 1097 n. 22.

34. There is no doubt that the status of being an American citizen is of unique im. portance to individuals. Schneiderman v. United States, 320 U.S. 118, 122 (1943). That a "benefit" is of great importance to those desiring it, however, is hardly a reason for allow. ing the government unlimited discretion in "distributing" it. On the contrary, the greater the individual's interest in obtaining the benefit, the more it would secm that a justifica. tion for its denial should be required. Cf. Kramer v. Union School District, 895 U.S. 621, 626 (1969); Douglas v. California, 373 U.S. 353, 358 (1968); Harper v. Virginla Board of Elections, 383 U.S. 663, 667 (1966); Griffin v. Illinois, 351 U.S. 12, 17 (1956); Charles Reich, The New Property 72 YALE L.J. 733, 781, 787 (1964); Michelman, infra note 108 at 13. The unique importance of citizenship is a justification for unfettered power, thercfore, only insofar as absolute discretion over naturalization is vitally important to the government.

35. There is also the possibility that a naturalized citizen's actions abroad may affect American foreign policy; but it will be argued that this consideration does not justify unfettered power. See pp. 780-84 infra.

36. A citizen, whether naturalized or native-born, cannot be deportcd. Ng Fung Fo v. White, 259 U.S. 276 (1922). 
tions would be accomplished through the law of crimes. That is, criminal sanctions both deter potential violators and enable the state to remove actual violators from the community, if not from the jurisdiction. Assuming that deportation and incarceration are substantially equivalent means for accomplishing those two functions, ${ }^{37}$ the state's interest in employing the former method is only that it avoids expense. 38

The second reason why the government might deport a person is that he has a status detrimental to the public welfare, such as a contagious disease, which represents both a drain on the economic resources of the nation and a threat to the health of others. The threat to the health of others can in turn be translated into an economic drain, since an alternative means of dealing with the threat would be to isolate the person in a hospital quarantine. ${ }^{39}$ Thus, the government interest in being able to deport persons with detrimental statuses, as was the case with those who commit detrimental actions, is that deportation is the least costly means of handling the problem.

A conseqence of limiting the naturalization power, then, would be that the government will be forced to incur some costs that it could otherwise avoid. The application of constitutional limitations to the naturalization power would undoubtedly result in the naturalization of some persons whom the government would otherwise disqualify, and the government would be forced to spend more money on those persons than if they had not been naturalized.

Additional expense, however, is ineluctable when any power is fettered. All other powers of the national government have been deemed fettered even though the necessary consequence has been that the government has had to incur greater costs to achieve its goals. ${ }^{40}$ That

37. Of course, they are not equally efficient. Deportation adds a measure of permanence not usually available with incarceration, even though the length of incarceration is presumably fitted to the gravity of the crime. The important point to keep in mind, however, is that limiting the naturalization power does not mean that the government is poirerless to prevent the naturalization of, for example, resident alien murderers and rapists. Assuming that there is a legitimate government interest in preventing naturalization of criminals, and it will be argued in a later section that there is, those persons with a propensity for serious crime can be weeded out. Thus, since those persons who are naturalized will have demonstrated during their five year probationary periods that they are law-abiding, there is no reason to believe that the loss in efficiency in achieving the above two goals will have any practical effect.

38. For example, there are costs of maintaining the person in prison that would be alleviated if he were deported.

39. The same argument can be made for most other detrimental statutes. The poor could be helped by welfare funds, the sick by health insurance, and the old by socinl security. In each case, all that the government must provide is monetary expenditures. But cf. pp. 808-09 infra.

40. Robert Dahe, A preface to Dexlocratic Theory 86 (19j0). 
is, an increase in expense for the government has been considered an acceptable price for a system of limited government powers. Since there is no reason to believe that the expense involved in limiting the naturalization power is especially large in comparison with the expense incurred in limiting other powers, powers which have been limited, it would not seem that this government interest in an unfettered naturalization power is, in quantitative terms, especially "vital."

The only way to distinguish the expense involved in fettering the naturalization power from that involved in fettering other powers is that the naturalization power affects the interests of resident aliens, rather than those of citizens. Only if resident aliens are less deserving than citizens in terms of what they can legitimately expect from government should the naturalization power be considered unique.

This issue is also raised by the last of the three effects of naturaliza. tion on the government/individual relationship-the requirement that government allow the individual to vote and to hold public office. That requirement must be considered in light of the facts that a) even after naturalization, the government can bar an individual from voting and holding public office if there is a compelling reason for doing so, ${ }^{41}$ and b) fettering the naturalization power will not mean that every alien will gain these rights through naturalization; rather, the government will simply need a constitutionally valid reason for disqualification. In other words, the consequences of fettering the naturalization power will be, not complete governmental impotence, but an inability to deny the vote and eligibility for public office to resident aliens for any reason which Congress alone deems sufficient. That inability is a justification for unfettered power only if absolute governmental discretion to bar resident aliens from the political process is implicit in, or at least consistent with, the resident alien/government relationship.

Thus, both the government interest in avoiding extra expenditures for resident aliens and the government interest in retaining absolute discretion to bar resident aliens from the political process can be reduced to the proposition that resident aliens are less deserving than citizens of governmental protection and benefits. The issue of unfettered power over naturalization, in short, turns on a value judgment concerning the place of resident aliens in American society.

The relationship between the resident alien and the national government consists of mutual obligations. The resident alien is required to give obedience and allegiance to the government; in return, he is

41. See pp. 800-03 infra. 
entitled to protection from the government. ${ }^{22}$ This type of reciprocity, furthermore, has been used by the Supreme Court to define the relationship of man to state known as "citizenship."13 Citizens, like resident aliens, are entitled to protection from the government in return for their assumption of the obligations of obedience and allegiance. It would seem, therefore, that a judgment concerning the protection to which resident aliens are entitled, relative to the protection afforded citizens, should depend on the extent of the resident alien's obligations, relative to those of citizens.

Resident aliens are required to obey all valid laws of the federal and state governments, ${ }^{44}$ and are fully taxed and fully liable to be drafted to fight for the United States. Further, resident aliens can be convicted of treason, indicating that they owe the government full allegiance. ${ }^{45}$ In short, resident aliens, as permanent members of the population, have the same obligations to the national government as do citizens. ${ }^{40}$ Therefore, if persons who are similarly situated with respect to their duties to government should be entitled to similar treatment from government, resident aliens should be able to enjoy the same protection from adverse government action as citizens.

This analysis of the relation between the alien resident and the state implies that if the government interest in avoiding costs is insufficient to justify unfettered power when citizens' interests are at stake, it should be likewise insufficient when resident aliens' interests are at stake. Further, if resident aliens are entitled to full protection, the government must be prohibited from arbitrarily infringing their interests, just as it is prohibited from arbitrarily infringing the interests of citizens. Put another way, the interests of resident aliens impose a limit on the ability of govermment to act. Thus, it is not "vitally important" that the government have absolute discretion to deny resident aliens the vote. On the contrary, the judgment that resident aliens should be

42. Wong Kim Ark v. United States, 169 U.S. 649, 694 (1898).

43. "Citizenship is membership in a political society and implies a duty of allegiance on the part of the member and a duty of protection on the part of the society. These are reciprocal obligations, one being a compensation for the other." Luria v. United States, 231 U.S. 9, 22 (1913). See also Minor v. Happersett, 88 U.S. (21 Wall.) 162, 165.6 (1874). 44. Carlisle v. United States, 83 U.S. (16 Wall.) 147, 154-5 (1873).

45. A person cannot be guilty of treason if he does not owe allegiance. An act which is treasonable if the actor owes allegiance is not treasonable if he does not. The rationale for a resident alien's liability for treason is that he receives the protection of the nation's laws and hence owes allegiance. Powers, Treason by Domiciled Aliens, 17 Alutrarr LAW REVIEW 123, 123-4. This theory was taken to its extreme in United States v. Shinohnra, Military Commission Cases No. 134819, where an enemy alien residing in a cerritory of the United States was held to orie allegiance, notwithstanding the fact that the territory was occupied by the enemy nation of which he was a citizen. Note, Treason, A Brief History, 29 BROOKLYN LAW REVIEW 254 (1956).

46. 2 Wharton INIERNATIONAI LAw Digest, Sec. 198 at 485 (1887). 
fully protected would seem to require that the government's ability to deny them the rights to vote and hold public office be limited.47

\section{Diplomatic Imperatives}

The argument that unfettered power over naturalization is justified because it allows for maximum flexibility in an area affecting foreign affairs seems untenable after the decision of the Supreme Court in Schneider $v$. Rusk. ${ }^{48}$ That case concerned the validity of a statute that provided that "a person who has become a national [citizen] by naturalization shall lose his nationality [citizenship] by . . . having continuous residence for three years in the territory of a foreign state of which he was formerly a national." 40 Since native-born citizens cannot be deprived of their citizenship for mere residence in a foreign nation, the statute clearly created an inequality between naturalized and nativeborn citizens.

The first clause of the Fourteenth Amendment, however, guarantees full rights of American citizenship to persons "naturalized in the United States"; ${ }^{50}$ and the Supreme Court has consistently held that naturalized citizens are fully equal with native-born citizens, except for a constitutional disability to be elected President.51

47. The American constitutional system assumes that the surest way to protect the populace from arbitrary government action is by having the people themselves, through their elected representatives, determine the substance of the laws which they must obcy. Thus, if the interests of resident aliens are to be fully protected, as their assumption of full obligations indicates, it is necessary that they be assimilated into the structure of consent-giving. Similarly, there seems to be no government interest in preventing a person who has demonstrated obedience and allegiance from holding public office if the pcople choose him.

Any other conclusion would result in the exclusion of a portion of the nation's popula. tion from the body politic, as did the Supreme Court's infamous decision in Dred Scott v. Sanford, 60 U.S. (19 How.) 393 (1857), excluding slaves.

48. 377 U.S. 163 (1964).

49. 8 U.S.C. $\$ \$ 1101,1484$ (1964). Schneider, a derivative American citizen who had married a German and settled in Germany, was refused a passport renewal by the Secretary of State, who claimed that she had lost her citizenship by virtue of her residence in Germany. Nearly twenty years earlier, a District of Columbia Court uscd a similar statute to uphold the expatriation and exclusion of a naturalized citizen for spencling twelve years in Palestine. Lapides v. Clark, 176 F.2d 619 (D.C. Cir. 1949). The Court gave the following reason for legislation, $i d$. at 621 :

To lessen friction with foreign governments growing out of disputes as to the nationality of our naturalized citizens and their offspring residing for prolonged periods in foreign lands.

50. "All persons born or naturalized in the United States, and subject to the jurisdiction thereof, are citizens of the United States and of the State whercin they reside." $U . S$. Const. amend. XIV, \& 1 .

"A naturalized citizen . . . becomes a member of the society, possessing all the rights of native citizens, and standing, in the view of the Constitution on the footing of a native. The Constitution does not authorize Congress to enlarge or abridge those rights." Osborn v. United States Bank, 22 U.S. (9 Wheat.) 738, 827 (1824).

51. See Baumgartner v. United States, 822 U.S. 665,673 (1944); Luria v. United States, 231 U.S. 9, 22 (1913). 
The government attempted to justify the statutory inequality under the foreign relations power, arguing that, since other nations frequently attempt to treat naturalized American citizens living abroad as their own citizens, the restriction was necessary to prevent the United States from becoming embroiled in diplomatic crises. ${ }^{62}$ The Supreme Court, stressing the constitutional requirement of equality between naturalized and native-born citizens, rejected the notion that the foreign relations power could justify the creation of "a second class citizenship," 53 and struck down the law. ${ }^{64}$

The Schneider holding has necessary implications for the doctrine of unfettered power over naturalization. As an alternative to the statute at issue in that case, Congress might as easily have attempted to achieve the same result through an explicit exercise of the naturalization power. ${ }^{55}$ For example, it might have decreed that naturalization conferred only limited rights to resident aliens, specifically withholding the right to live abroad. Alternatively, Congress might have required applicants for naturalization to take an oath that they would never reside abroad, or that they would "voluntarily" relinquish their citizenship if they did so. ${ }^{56}$ Either of these alternative statutes-explicit exercises of the naturalization power-would have achieved the same

52. The treaty power had frequently been used to aroid this kind of international tension. Agreements were negotiated to the effect that naturalized citizens would lose their citizenship if they were to reside for an extended period in their native country. See es.s. the Bancroft treaty with the North Germany Confederation, 15 Stat. 615, 616, 617 (1868).

53. 377 U.S. at 168-69.

54. The Schneider holding was not shaken, although it was limited in scope, by the recent Supreme Court opinion in Rogers v. Bellei, 39 U.S.L.W. 4354 (April 6, 1971), upholding statutory provisions granting citizenship at birth to a person born abroad to parents, one of whom is an American citizen who has met specified residency requirements, but providing that such citizenship is revoked unless the person resides in the United States for five years between the ages of fourteen and twenty-cight. Justice Blackmun's majority opinion turns on a strict reading of the initial sentence of the Fourteenth Amendment, which refers to persons "born or naturalized in the United States, and subject to the jurisdiction thereof:" (emphasis added). The Court limited Selineider to persons who are naturalized in the United States, according to the procedures outlined in Section I above. This Note, insofar as it argues from the functional equivalence, in terms of duties and obligations, between resident aliens and citizens, has implicitly adopted the same limitation-without, of course, necessarily implying agreement with the Bellei ase.

55. The statute invalidated in Schneider was apparently not an cxplicit excrcise of the naturalization power. It was placed in chapter 3 of the Immigration and Nationality Act of 1952, which was entitled "Loss of Nationality." That chapter included provisions withdrawing nationality from both native-born and naturalized citizens. Thus, unlike chapter 2, which dealt only with naturalization, chapter 3 apparently vent bejond the ambit of the naturalization power.

56. During the first half of this century, the Supreme Court upheld an oath requiring that applicants for naturalization pledge to relinquish rights enjojed by native born citizens. See United States v. Macintosh, 383 U.S. 605 (1931); United States v. Schwimmer, 279 U.S. 644 (1929). Petitioners were rejected unless they pledged, as an indication of their allegiance to the nation, a willingness to bear arms. At the same time, native born citizens were, if they met certain criteria, legally entitied to conscientious objector cremp. tions from combatant service. 
diplomatic objectives, and created the same "second class citizenship," as the provision at issue in Schneider.67

It seems highly unlikely that such legislative action, unjustifiable under the foreign relations power, could be upheld under the naturalization power. Almost thirty years before Schneider, the Supreme Court had made it clear that the national government, when acting in the international arena pursuant to the foreign relations power, possesses all powers which inhere in the concept of national sovereignty. ${ }^{68} \mathrm{~A}$ statute passed pursuant to the naturalization power, therefore, could not draw upon any additional or greater "sovereign powers" than those which were exercised in passing the statute at issue in Schneider.

Moreover, the government's attempted justification for the statute in Schneider-the need to avoid diplomatic disputes-is identical with the "diplomatic imperatives" justification for unfettered power over naturalization..$^{00}$ In the Schneider situation, international friction might be caused by other nations treating naturalized Americans living abroad as their own citizens; in the naturalization context, it might be caused by the United States treating the citizens of other nations as its own citizens. Since maximum flexibility in avoiding international friction was deemed insufficient to justify creation of a "second class citizenship"

In Girouard v. United States, 328 U.S. 61 (1946), the Supreme Court overruled its earlier decisions denying naturalization to applicants who refused to take such an oath. The decision, however, turned on statutory construction, rather than constitutional interpretation. Congress, the Court determined, had demanded only that applicants pledge their allegiance; and, since an unwillingness to serve in a combatant capacity was traditionally not inconsistent with allegiance, the Justices "could not assume that Congrcss intended to make such a [requirement] . . . unless it spoke in uncquivocal terms." Id. at $64-65$.

57. The first alternative would clearly create a second class citizenship. Similarly, regarding the second alternative, naturalized citizens who had taken an oath to restrict their activities would not be free to fully enjoy rights possessed by native-born citizens. (The source of the right-that is, whether it is constitutional or statutory-is of no consequence. But see, to the contrary United States v. Macintosh, 283 U.S. at 623; IowA stupra. note 4, at $1106 \mathrm{n}$. 63. Full equality between naturalized and native born citizens cannot exist un. less the former can enjoy all the rights which the latter enjoy, regardless of source.) if the oath were legally binding after naturalization, that is, if the new citizens were deemed to have waived the right to act as natives may, then the inferior status of naturalized citizens would be clear. And, even if it were held that the oath was not legally binding after naturalization, that is, that it could be required of applicants but not enforced after the petition was granted, naturalized citizens would still not be on the same footing as native born citizens. First, it must be assumed that some naturalized citizens will feel honor-bound to abide by their solemn oaths, even in the absence of lcgal compulsion. Cf. Baggett v. Bullitt, 377 U.S. 360, 374 (1964). And second, aliens who fraudulently obtain citizenship can be denaturalized. 8 U.S.C. 1451 (1954). A naturallzed citizen who had taken the oath with the intent to break it could therefore lose his citizenship; and, more importantly, the risk of appearing to have taken the outh fraudu. lently would likely deter some naturalized citizens who had taken it honestly but sub. sequently changed their mind.

58. United States v. Curtiss-Wright Export Corp., 299 U.S. 304, 315.18 (1936).

59. Certainly there is no reason to believe that the naturalization power incorporates any greater inherent sovereign powers than does the foreign relations powcr.

60. Cf. Lapides v. Clark, 176 F.2d 619, 621 (D.C. Cir. 1949). 
through the Schneider statute, the conclusion seems compelled that the same consideration would be insufficient to justify creation of an identical "second class citizenship" through a naturalization statute, which could draw upon no greater "sovereign powers" than the Schneider statute.

In short, the necessary implication of Schneider $v$. Rusk is that the naturalization power is limited, at least so far as it is exercised to abridge the rights of naturalized citizens. ${ }^{\circ 1}$

There is no reason, however, to limit the scope of Schneider's implications for the naturalization power to the rights of naturalized citizens. In fact, the invalidity of the hypothetical oath requirement, mentioned

61. It is clear that the constitutional rights of naturalized citizens impose the following limit on the power of Congress to make rules for naturalization: Congress may not condition naturalization on a pledge to act in a way restricting the rights of citizenship; nor may it, in any other manner, use the naturalization power to create a limited or restricted class of citizens.

Under this rule, an argument might be made attacking the validity of the oath of allegiance in the present statute. 8 UU.S.C. 1448 (1954). It does not demand a pledge to bear arms; but, as a demonstration of allegiance, the applicant must swear either to bear arms, or, if he can prove by clear and convincing evidence that he is unable to do so because of religious training or belief, to accept conscientious objector status, and, if required by law, to perform noncombatant military or civilian duties.

This oath is clearly less restrictive than the one at issue in Girouard; but it does preclude naturalization for aliens who object to war for nonreligious reasons or who object only to particular wars. See e.g., In re Weitzman, 284 F. Supp. 514 (D.C. Arinn. 1908). This oath does not require a pledge to refrain from exercising "lggal rights." In cssence, it requires nothing more than a promise to act in accordance with a particular law, the statute concerning conscientious objector status and noncombatant service, which applies to all citizens. Nevertheless, it may be subject to attack.

There is a question as to whether this oath is sufficiently related to a legitimate legislative purpose to withstand a challenge under the Due Process Clause. The purpose of the oath of allegiance, as the Court assumed in Girouard, 328 U.S. at 61-65, is to ensure that naturalized citizens are loyal to the United States. To that end, the alien, before he can become a citizen, is required to swear that he will demonstratc his allegiance by performing, after naturalization, a specific act, acceptance of required national service. Some naturalized citizens, therefore, those who took the oath honestly but changed their beliefs after naturalization, may be coerced, by honor or the threat of denaturalization and deportation, to accept national service (rather than a jail tcrm).

A constitutional difficulty may arise because, at least insofar as expatriation and denaturalization proceedings are concerned, the Supreme Court has held that no one act is sufficiently probative of a person's allegiance to the nation to be, by itself, controlling. See Afroyim v. Rusk, 387 U.S. 253 (1967) (voting in a foreign election): Trop v. Dulles, 356 U.S. 86 (1958) (desertion in wartime). See also Kennedy v. Mendoza-Afartinez. 372 US. 144, 187 (1963) (Brennan, J., concurring); Note, 59 Mfich. L. REv. 960, 93 (1961) (draft evasion). Certainly a refusal to bear arms or accept other national service becuse of sincere religious or moral beliefs is not necessarily inconsistent with allegiance to the nation. Thus, although the fact that an applicant had refused to bear arms or accept alternative service while a resident alien, or intended to so refuse after naturalization, undoubtedly has some probative value regarding nonallegiance (so that questions on the subject would be relevant to a general investigation of his allegiance), it is questionable whether a promise not to refuse in the future is, by itself, sufficiently probative under the Due Process Clause to justify the coercion of naturalized citizens. Compare Schware v. Board of Bar Examiners, 353 U.S. 232, 246-7 (1957) and Konigsberg v. State Bar of California, 353 U.S. 252 (1957) with Konigsberg v. State Bar of California, 365 U.S. 36 (1961). (Past Communist Party affiliation is not a proper ground for refusing admission to the bar, but questions on that subject can be asked in a general investigation of the appliant's fitness.) 
above, indicates that Schneider's scope includes the resident alien. Although the reason the oath would be invalid is that it would abridge the rights that will be the resident alien's after he becomes a naturalized citizen, the constitutional prohibition against such an oath, to be effective, must be enforcible against the government by the resident alien-the power is not unfettered with respect to him.

Once it is established that the naturalization power is limited with respect to the resident alien, it should be clear that he must be able to assert, not only the rights that will become his after naturalization, but also rights which are his as a resident alien. If resident aliens are to be protected from adverse government action as fully as citizens, as their assumption of equal obligations implies, a power which is fettered with respect to citizens' rights must also be fettered with respect to resident aliens' rights. Even if different constitutional rights are assumed to be of different "importance," ${ }_{2}$ it would not follow that government power is unfettered with respect to the "lesser" rights. Rather, the importance of the right would be considered in the accommodation which is made when the power is exercised to create a conflict between the right and governmental interests.

In sum, since the rationales for unfettered power over naturalization are inadequate, and since there are strong countervailing considerations in both policy and case law, the doctrine should be abandoned. ${ }^{03}$

\section{Denial of Naturalization on the Basis of a Resident Alien's Voluntary Actions}

\section{A. The Doctrine of Unconstitutional Conditions}

The doctrine of unconstitutional conditions was developed ${ }^{04}$ in order to prevent individuals from being forced to choose between disqualifi-

62. Although it might be argued that some constitutional rights have "primacy" over others, it cannot be assumed that the same right is less important when possessed by a resident alien than by a citizen. First, there is no indication in the constitution that the First Amendment, the Due Process Clause, and the Equal Protection Clause, among other provisions, protect resident aliens to a lesser degree than citizens. Second, if resident aliens are to be fully protected in American society, as their assumption of equal duties and obligations suggests, their rights must be of the same scope as citizens'. Further, there is no indication in the cases dealing with aliens (in contexts other than exclusion, deportation, and naturalization), that the rights of aliens are of less consequence than those of citizens, See note 2 supra.

63. Further, if the naturalization power is limited, the deportation power must be. since deportation precludes naturalization, it is clear that all restrictions on congressional power to refuse naturalization also apply to the deportation power. Grounds for dcportation are not valid, in other words, unless they could also be grounds for denlal of naturalization.

64. For general discussion of the early cases expounding the doctrine sce Hale, $U n$. constitutional Conditions and Constitutional Rights, 35 CouvM. L. REv. 821 (1935); Merrill, 
cation for governmental benefits and the exercise of constitutional rights. ${ }^{65}$ Generally, the doctrine holds that even though the government is not obligated to provide a benefit, that is, even though the benefit is a "privilege," it may not be withheld or cancelled for the exercise of constitutional rights. ${ }^{66}$ The concern has been with both the unfairness of such sanctions ${ }^{67}$ and their substantial "chilling effect" ${ }^{108}$ on the exercise of important rights. ${ }^{69}$

The doctrine of unconstitutional conditions does not impose a mechanical test. Generally, however, in order to justify the withholding of a benefit from a person because he performed an act which is constitutionally protected in other contexts, the government must prove: 1) that the condition imposed is closely related to the nature of the benefit granted, ${ }^{70}$ or 2) that the condition protects important social interests from persons whose capacity for inflicting damage would be substantially increased by possession of the benefit. ${ }^{71}$ In addition, the doctrine of less drastic means applies. ${ }^{72}$ That is, even if one of the above criteria is met, a court must weigh the degree to which the exercise of

Unconstitutional Conditions, 77 UNIv. of PA. L. REv. 879 (1929); Oppenheim, Unconstitutional Conditions and State Powers, 26 Mirch. L. REv. 176 (1927). For more recent treatment see O'Neill, Unconstitutional Conditions: W' 54 CALrF. L. REv. 443 (1966); French, Unconstitutional Conditions: An Anal;sis, 50 Gzo. L.J. 234 (1961); Note, Unconstitutional Conditions, 73 HARv. L. REv. 1595 (1960); Willcox, Invasions of the First Amendment Through Conditional Public Spending, 41 Corweu. L. REv. 12 (1955); Note, Judicial Acquiescence in the Forfeiture of Constilutional Rights Through Expansion of the Conditioned Privilege Doctrine, 28 INouNA L.J. 520 (1953).

65. The exercise of constitutional rights can be inhibited in two ways. First, negative sanctions such as imprisonment, fines, or a tax might be imposed on persons who exercised certain rights. Second, there are "positive sanctions"-government distribution of benefits conditioned on a recipient's "voluntary" non-cxercise of certain rights. Thus, instead of being imprisoned or fined, an individual who acts in a certain manner may be disqualified for public employment, McAuliffe $v$. New Bedford, 155 N fass. 216,29 N.E. 517 (1892), professional licensing, Spivack v. Klein, 385 U.S. 511 (1967), social sccurity benefits, Flemming v. Nestor, 363 U.S. 603 (1960) -or naturalization.

66. Note, Unconstitutional Conditions, 73 HARv. L. REv. 1595, 1599 (1960). See Stcin. berg v. United States, 163 F. Supp. 590, 592 (Ct. Cl. 1958). See also Speiser v. Randall, 357 U.S. 513, 518-20 (1958). But cf. Wyman v. James, 91 S.Ct. 381, 386 (1971).

67. Slochower v. Board of Education, 350 U.S. 551, 555 (1950); Wieman v. Updegraff. 344 U.S. 183, 192 (1952). See Patton v. North Carolina, 381 F.2d 636 (1th Cir. 1967), cert. denied, 390 U.S. 905 (1968).

68. Cf. Note, Civil Disabilities and the First Amendment, 78 YAL L.J. 842 (1969). SeC Baggett v. Bullitt, 377 U.S. 360, 372 (1964).

69. The growth of judicial concern can be traced by comparing MeAuliffe $v$. New Bedford, 155 Mass. 216, 217; 29 NE. 517, $517-518$ (1892); Bailcy v. Richardson, 182 F.2d 46, 57, 59 (D.C. Cir. 1950); Adler v. Board of Education, 342 U.S. 485, 492 (1952), with Garrity v. New Jersey, 385 U.S. 493, 499-500 (1967); Kejeshian v. Board of Regents, 385 U.S. 589, 599-600 (1967).

70. The focus has been on whether the condition bars the individual in a "patently arbitrary or discriminatory" manner. TVieman v. Updergraff, 344 U.S. 183, 192 (1952); Speiser v. Randall, 357 U.S. 513, 518-19 (1958). See Lawsen v. Housing Authority, 270 wis. 269, 287; 70 N.W.2d 605, 615; cert. denied, 350 U.S. 882 (1955). But see Fleming v. Nestor, 363 U.S. 603 (1960).

71. These rules are suggested in Note, Unconstitutional Conditions, 73 HAnv. L. REv: 1595,1600 (1960).

72. Cf. Shelton v. Tucker, 364 U.S. 479, 488 (1960). 
important constitutional rights is discouraged against the difference in efficiency between the condition imposed and another condition less restrictive of constitutional freedoms..$^{73}$

The doctrine of unconstitutional conditions, then, does not assume that any rights are "absolutely" protected. Rather, it holds that if certain actions have been deemed protected in contexts unrelated to the granting of a benefit, they cannot be made grounds for denying the benefit unless the above test is satisfied.

The applicability of the doctrine of unconstitutional conditions to requirements in the naturalization statute cannot be avoided by the contention that, although Congress cannot directly penalize resident aliens for constitutionally protected actions in a non-naturalization context, it can evaluate the manner in which they exercise their rights in determining their "worthiness" for naturalization. ${ }^{74}$ Although Congress may legitimately attempt to restrict naturalization to those aliens who are worthy of citizenship, ${ }^{75}$ actions which are constitutionally protected should be per se irrelevant to a determination of unworth. ${ }^{70}$ In short, if standards of constitutional adjudication are applied to the naturalization process, the doctrine of unconstitutional conditions is applicable.

\section{B. Application of the Doctrine to the Present Statute and to Admin- istrative Practices ${ }^{77}$}

Much of the history of deportation and naturalization laws in the United States can be written in terms of congressional efforts to rid the nation of political radicals. ${ }^{78}$ To avoid banishment or disqualification

73. Cafeteria Workers Union v. McElroy, 367 U.S. 886 (1961); Homer v. Richmond, 292 F.2d 719 (D.C. Cir. 1961).

74. Such a contention was made by the Supreme Court in United States ex rel. Turncr v. Williams, 194 U.S. 279, 292 (1904); cf. Trop v. Dulles, 356 U.S. 86, 124 (1958) (Frankfurter, $J$., dissenting).

75. See pp. 798-802 infra.

76. By definition, the fact that an act is protected means that it has enough soclal worth to justify a limitation on the power of government. In other words, cven though a person's life style or philosophy is obnoxious to the majority, his actions are "worthy" at least to the extent that they are constitutionally protected-for to that extent the social value of his actions outweighs the discomfort or harm caused to the miljority, See Maisenberg v. United States, 356 U.S. 670 (1958); Nowak v. United States, 356 U.S. 660 (1958); Schneiderman v. United States, 320 U.S. 118 (1943). Actions with social valuc such that government cannot "reach them" in other contexts cannot be rational grounds for denial of a benefit on the grounds of unworthiness.

77. In the following section, the doctrine of unconstitutional conditions is applied to first amendment rights, since those rights are abridged by the present statute. However, the argument would apply as well to other rights, for example, the right to a jury trial, or "private" actions protected from governmental interference by Griswold va Con. necticut, 381 U.S. 479 (1965). In connection with the right to privacy, see 8 U.S.C. 1182 (1954) dealing with sexual perversion. See also Boutilier v. I.N.S., 887 U.S. 118 (1967). Cf. In re Labody, 39 U.S.L.W. 2558 (S.D.N.Y., April 13, 1971).

78. It was observed in 1948, KansoN, U.S. InIMIGRATION 206.26 (1948), that every major 
for citizenship, the resident alien has had to be a political conformist, or at least a silent critic of the system. ${ }^{78}$

The present statute continues in this tradition. It provides that "no person shall hereafter be naturalized ... who advocates or teaches ... opposition to all organized government; or . . . who . . . advocates the economic, international, and governmental doctrines of world communism or the establishment in the United States of a totalitarian dictatorship."80 It is clear from decisions in other contexts, however, that mere advocacy of abstract doctrines-whether of communism, anarchism, or totalitarianism-is speech protected by the First Amendment. Advocacy can be outlawed only when it incites illegal action; ${ }^{81}$ but the act makes no such distinction.

In addition, the statute precludes naturalization for any alien who is a member of, or affiliated with, the Communist Party, other communist organizations, or other organizations devoted to various undesirable purposes. ${ }^{82}$ Membership by itself is sufficient; ${ }^{83}$ there is no

change in the law had broadened the political grounds for deportation or denial of naturalization. In the Alien and Sedition Act of 1798, I Stat. 570, June 24, 1798, the President was empowered to deport any alien he found dangerous to the peace and safety of the nation. In 1903, Congress provided for deportation and denial of naturaliztion for mere belief, devoid of action or advocacy. Act of Mlarch 3, 1903, ch. 1012, 32 Stat. 1214. See Turner v. Williams, 194 U.S. 279 (1904). In 1918, the hiw was amended to broaden the range of prohibited political views. Act of Oct. 15, 1918, ch. 186 Sec. 1, 40 Stat. 1012. And, two years later, governmental suppression of aliens' expression culminated in the infamous Palmer "red raids." See L. Post, THE Deportation Decenuuas of 1920 (1923). The purpose behind these acts was stated by the Bureau of Naturalization: "As long as the advocates of these malignant and un-American doctrines remain aliens, they may be deported and their gospels may be overthrown at their inception, but once they succeed in obtaining their citizenship, this method of punging our country becomes more difficult, if not impossible." Bureau of Naturalization Radio Release No. If, Oct. 16, 1922, as noted in W. PRESTON, ALIENS AND DISSENTERS 64 (1963). The following excerpts from the Congressional Record are illustrative of the attitude of some legishators toward aliens: "Now, I would execute these anarchists if I could, and then I would deport them, so that the soil of our country might not be polluted by their presence esen after the breath had gone out of their bodies." 51 Cong. REc. 2892 (1914) (remarks of Rep. Slajden). "Free press is ours, not theirs; free speech is ours, not theirs, and they have gone just is far as we can let them go toward running over our most precious rights." 59 CoNG. REC. 9247 (1920) (remarks of Rep. Johnson).

79. W. PRESTON, At.TENS AND Dissenters, supra note 78, at 82 . Cf. Commager, Who is Loyal to America? 195 Harpers 193, 195 (1947).

80. 8 U.S.C. 1424 (1964). This has permitted courts to reject petitioners who have done nothing more than teach or believe in the principles of anarchy or Communism. See Petition of Millan, 266 F. Supp. 545, 551-52 (C.D. Calif. 1967). The statute also forbids a finding of good moral character for any alien advocating polygamy, 8 U.S.C. 1182 (11) (1964).

81. The essential distinction is that those to whom the adrocacy is addressed must be urged to do something, now or in the future, rather than merely to believe in something. Yates v. U.S., 354 U.S. 298, 312 (1957). See Keyishian v. Board of Regents, 385 U.S. 589, 599 . 600 (1967). While the above cases were criminal, the Court has refused to allow the with. drawal of benefits for advocacy that could not be criminally punishable. Speiser v. Rnndall, 357 U.S. 513, 519 (1958); cf. Thompson v. Gleason, 317 F2d 901, 906 (D.C. Cir. 1962).

82. 8 U.S.C. 1424 (1964).

83. See Berenyi v. Immigration Director, 385 U.S. 630 (1967); Galvan v. Press, \$47 U.S. .522 (1954). Even membership in a predecessor or successor organization, regardiess of its 
requirement that it be knowing, active, and with the specific intent to further illegal objectives. ${ }^{84}$ Yet the Supreme Court has insisted on such a requirement before membership can be discouraged by criminal statutes. ${ }^{85}$ Prohibition or discouragement of any association with organizations having both legal and illegal purposes, ${ }^{80}$ without regard to the nature and degree of affiliation, is impermissible under the First Amendment. ${ }^{87}$

name, is sufficient. Citizenship can thus be denied for membership in, or affiliation with, a group that did not evidence alignment with a prohibited group.

84. 8 U.S.C. 1424(d) (1964) provides that membership in a disfavored organization is not disqualifying if the alien can prove that the membership has been terminated and that it was coerced by law, necessary to obtain the essentials of living, involuntary (i.t. mistaken), or terminated before the age of sixteen.

85. U.S. v. Robel, 389 U.S. 258, 262 (1967); Aptheker v. Sccretary of Statc, 378 U.S. 500,510 (1964); Scales v. U.S., 367 U.S. 203, 229 (1961).

86. Schneiderman v. U.S., 320 U.S. 118, 136 (1943): "[B]eliefs are personal and not a matter of association ... men in adhering to a political party or other organization notoriously do not subscribe unqualifiedly to all its platforms or asserted principles."

87. Scales v. U.S., 367 U.S. 203, 229 (1961). See Chicago Housing Authority v. Blackman, 4 IIl. 2 d 319,122 N.E.2d 522 (1954) (members of an organization designated by the Attorney General as subversive may not be denied public housing unless their knowledge and sup. port of the aims of the organization are considered).

In 1945, the Supreme Court hinted that a First Amendment limit on deportation statutes might exist. Bridges v. Wixon, 326 U.S. 135 (1945). In that case, the government had attempted to deport a resident alien who, while not a member of the Communist Party, was "affiliated." Id. at 156. Although the decision turned on statutory construction, the Court implied that its construction was necessary to avoid First Amendment dif ficulties. Id. at 148. This aspect of the decision, however, has not been further cleveloped by the Court.

It should be noted, additionally, that the statutory provision denying naturalization to members of the Communist Party is also vulnerable to attack as a bill of attainder pro. hibited by Article I, Section 10 of the U.S. Constitution. On its face, there is no indication that the prohibition protects only citizens; and the contrary is suggested in United States $v$. Lovett, 328 U.S. 303, 315-16 (1946). The clause prohibits any legislative act which "tries" or "punishes" a named or easily ascertainable person or groutp of persons without a judicial trial. Id. at 315-17; see Ex parte Garland, 71 U.S. (4 Wall.) 333, 377; United States v. Brown, 381 U.S. 437, 442 (1965).

Attempts to apply the Bill of Attainder Clause to deportation and naturalization laws have been frustrated by two limitations traditionally placed on its application. Sce Iowa supra note 4, at 1107:

1) The imposition of punishment is considered to be an essential element of a bill of attainder. Otherwise, the statute is regarded as a permissible regulatory action. Cf. HIawker v. New York, 170 U.S. 189, 196 (1898). Yet, deportation or denial of citizenship, properly viewed, are "punishments" for purposes of the Bill of Attainder Clause. Although deportation or denying naturalization to Communist Party members has been con sidered an attempt to "prevent" disloyal acts, the Supreme Court has recognized that punishment, as it relates to the bill of attainder provision, can be preventive as well as retributive. United States v. Brown, 381 U.S. 437, 441-42. Deportation has been recognized as punishment in other contexts. Fong Haw Tan v. Phelan, 333 U.S. 6, 10 (1948). Further, inherent in the denial of citizenship is denial of the franchise, a traditional mcans of punishment under the English "bills of pains and penalties," from which the Amcrican concept of Bill of Attainder is partly derived. United States v. Brown, 381 U.S. at 441.42 .

2) Another element of a bill of attainder is reference to an inescapable class. Communist Party v. Subversive Activities Control Bureau, 367 U.S. 1, 88 (1961). As a group, the Com. munist Party is clearly an inescapable class, for regardless of changes in its aims and purposes, its members would be excluded. Individual members can of course leave the Party, but the bill of attainder prohibition cannot be averted by asserting that a person can give up lawful membership in a named association. See Aptheker $\checkmark$. Secretary of State, 378 U.S. 500, 507 (1964).

Further, in 'Brown, the Supreme Court adopted an expansive interpretation of the 
In addition to the literal application of specific statutory provisions, the wide discretion wielded by special inquiry officers has reportedly been used in ways inconsistent with protected expression. Several of the lawyers interviewed reported that special inquiry officers often ask petitioners a wide range of "opinion questions" in an effort to determine if they are "subversive." Since the officers' determinations are virtually never reviewed, they are free to base findings of disqualification under the statute's moral character or political activity provisions on "unsatisfactory" answers. As an example of the use of administrative discretion against political "radicals," one lawyer related the case of an alien (unnamed because proceedings are still pending) who was found by an INS official to be of poor moral character for the sole reason that he had signed a petition opposing the war in Indochina and had spoken at an antiwar rally on a college campus. ${ }^{88}$

- These statutory provisions and administrative practices are unconstitutional unless the test outlined above is satisfied. That, however, is highly unlikely. First, there is little apparent relationship between the benefit conferred and the condition imposed-the non-exercise of constitutional rights certainly is a strange criterion of eligibility for formal "membership" in the constitutional system. Second, since by definition constitutionally protected actions are consistent with the national wellbeing, there is no important social interest served by discouraging such actions. ${ }^{89}$

In addition, the free speech rights of citizens require that the First Amendment rights of resident aliens not be "chilled" by conditions in the naturalization statute; for, unless the rights of expression and association of resident aliens and citizens are coextensive, discrimination against classes of citizens will result. If, for example, both Pro-X and

clause, viewing it as a corollary of the principle of separation of powcrs. 381 U.S. at 442. Congress can adopt general rules requiring that any person (or group) who commits specified acts or possesses specified characteristics be treated in a certain way. It cannot determine which particular persons or groups have committed the specific acts or possess the specified characteristics. 381 U.S. at 461 . Yet Congress has done precisely that in denying citizenship to Communist Party members. It has not enacted a general rule prohibiting the naturalization of persons who are disloyal or dangerous, leaving the application of the rule in specific cases to the judiciary. Rather, Congress has usurped the judicial function by making the determination that specific persons-alien Communist Party members - come within the prohibited class. Id.

In sum, Congress may not, in violation of the bill of attainder prohibition, conclusirely presume any individual or specified group of individuals to be incligible for maturalization.

88. He had never been arrested; nor had he engaged in acts of violence. The exact context of these acts was not made clear, but the lawjer clearly stated his opinion that the acts were constitutionally protected.

89. And even if there were such an interest, it would be furthered only slightly by a law affecting only a small part of the population. Citizens would be free to perform the very same acts. 
Anti-X speech are protected for citizens, but only Pro-X speech is protected for resident aliens, then the citizen-advocates of " $\mathrm{X}$ " would be given an unnecessary and entirely artificial competitive advantage over citizen-advocates of Anti-X. The Pro-X Party could benefit from resident alien membership and advocacy, while the Anti-X Party could not. This discrimination would be even more serious if the difference in protection between citizens and resident aliens were carried over into the naturalization process. If Pro-X aliens could be naturalized but Anti-X aliens could not, the government would be impermissibly in. creasing the voting power of the Pro-X Party relative to the Anti-X. Party. Thus, in order to prevent a skewing of the natural competition of ideas and votes among citizens, it is necessary that aliens within the jurisdiction be free to engage in the full range of expression that is protected for citizens.

Furthermore, the capacity of aliens to inflict real social harm through unprotected actions would not be significantly increased by the possession of citizenship. Unprotected actions which injure the public interest are (or can be made) criminal; and criminal statutes, of course, are applicable to naturalized citizens as well as resident aliens..$^{00}$

Denying naturalization on the basis of constitutionally protected actions, then, substantially furthers no important social interest; and the social interest in discouraging unprotected actions harmful to the state can be adequately protected by denying naturalization to aliens who have engaged in such actions, and by criminally prosecuting all members of the population-citizen and alien alike-who do so.

The rights abridged by current statutory provisions and administrative practices-expression and association-are of paramount importance both for the individual and the social system.01 Further, the degree to which the exercise of those rights is discouraged must be substantial, for it would be difficult to overestimate the value of the privilege conferred.92 Not only is the coercion powerful, its effect is broad in scope. Since under the doctrine of unfettered power there is no ex post facto limitation on Congress or the INS, the resident alien will be forced to steer wide of expression or association which might be

90. In fact, denying citizenship to aliens with unpopular political vicws might well increase the possibility of political violence. If access to the ballot box, the traditional means of instigating social and economic change in the United States, is denied to the resident alien, he may resort to other means of exerting pressure on the political system.

91. EMERSon, supra note 2, at 10.

92. "By many it is regarded as the highest hope of civilized men." Schneiderman $v$. United States, 320 U.S. at 122 (1943). Citizenship is a prerequisite for voting, running for many offices, and being licensed to practice many professions. 
deemed suspicious in the future when he files his petition. ${ }^{03}$ In sum, confronted with a choice between full expression or "playing it safe" for five years and qualifying for citizenship, many aliens undoubtedly choose the latter.

It seems clear that the test imposed by the doctrine of unconstitutional conditions is not satisfied with respect to numerous statutory provisions and administrative practices in the present naturalization process. The conditions imposed by these provisions and practices are irrelevant to the nature of the benefit conferred by naturalization. Further, the individual rights at stake are important, and are abridged significantly. Thus, the statutory provisions at issue must either be invalidated or construed to meet constitutional requirements; and the reported administrative practices can be challenged and should be terminated.

\section{Limitations from the Equal Protection Clause}

The argument in the preceding section is only applicable to requirements for naturalization which are based on voluntary actions. A person cannot be induced or coerced to give up traits which are normally unchangeable-involuntary statuses such as race, sex, national origin, age, poverty, ${ }^{94}$ or disease..$^{95}$

Under the present statute, no resident alien can be naturalized who:

93. An analogous self-censorship has been disfavored in loyalty oath and pornography cases. Baggett v. Bullitt, 377 U.S. at 372 (1964); Smith v. California, S01 U.S. 147, 153 (1959).

94. Poverty, properly viewed, is not a roluntary condition stemming from an individual's lack of initiative, but rather an involuntary status. See Mfichass Harrsicton, TrE OTHER AMERIGA; POVERTY IN THE UNITED STATES 18-19 (1964).

95. The present statute specifies that naturalization cannot be denied for reasons of race or sex, 66 Stat. 239 (1952), 8 U.S.C. $\$ 1422$ (1956); but such restrictions were not mre in the past. In 1790, the first naturalization statute, 1 Stat. 103, disqualified all individuals except free whites. Chinese were specifically excluded from immigration and naturalization by the Chinese Exclusion Acts of 1882, 1888 and 1892.22 Stat. 58, 25 Stat. 504, 27 Stat. 25. While races indigenous to the Western Hemisphere were made qualified in 1910, 54 Stat. 1140, restrictions remained for: Japanese, Ozawa v. United States, 260 U.S. 178 (1922); Chinese, Fong Yue Ting v. United States, 149 U.S. 698 (1893); Hindus, Samras v. United States, 125 F.2d 879 (9th Cir. 1942), cert. denied, 317 U.S. 634 (1942); Áfgans, In re Fcroz Din, 27 F.2d 568 (N.D. Calif. 1928); Burmese, In re Po, 28 N.Y. Supp. 383 (1894); Hnwaiians, In re Kanaka Nian, 21 P. 993 (Utah 1889).

The congressional explanation for such restrictions was set forth in the Chines Exclusion Cases, 130 U.S. at 595 (1889).

Even as the last vestiges of overt racial restrictions were repealed in 1952, Representative Wood of Idaho, commenting on the proposed Immigration and Naturalization Act. said: "It seems to me that the question of racial origins, though I am not a follower of Hitlerthere is something to it. We cannot tie a stone around its neck and drop it into the middle of the Atlantic just because it worked to the contrary in Germany. The fact still remains that the people of Western Europe have made good American citizens." Cosic. REc. 82d Cong., 2d Sess. 4314 (1952). 
is under eighteen years of age; ${ }^{26}$ is or was at any time after entry a drug addict; ${ }^{97}$ is an habitual drunkard; ${ }^{08}$ is mentally insane, defective, or retarded; ${ }^{99}$ does not understand English; ${ }^{100}$ or has, during the previous five years, spent more than 180 days in a penal institution (regardless of when the offense was committed).101 In addition, several of the lawyers interviewed reported that special inquiry officers weigh involuntary statuses when making discretionary judgments. Aliens who have certain diseases-venereal diseases, for example-or who receive welfare payments are, according to these lawyers, often deemed lacking in good moral character. ${ }^{102}$

The validity of governmental classifications of individuals on the basis of their involuntary statuses has been traditionally analyzed under the Equal Protection Clause, which is applicable to the national government through the Due Process Clause. ${ }^{103}$

\section{A. Legislative Purposes}

The preliminary steps in an equal protection analysis of laws or administrative practices purportedly justified under an enumerated congressional power concern legislative purpose. First, a determination must be made as to the purpose(s) a particular provision was intended to further. And second, it must be determined whether that purpose(s) is "legitimate."

Those determinations, seldom easy, ${ }^{104}$ are especially difficult with respect to the naturalization power, since judges and legislators, accepting the doctrine of unfettered power, have not found it necessary to

96. 8 U.S.C. § 1445 (1964).

97. 8 U.S.C. $\$ \S 1429,1251(11)(1964)$.

98. 8 U.S.C. \& $1101(\mathrm{f})(\mathrm{I})(1964)$.

99. 8 U.S.C. $\$ \S 1429,1182$ (1964).
100. 8 U.S.C. § 1423 (1964).

101. 8 U.S.C. \& 1101(f)(7)(1964).

102. One of the lawyers interviewed reported that his "congressional sources" had told him of "grumblings" that some legislators are considering a statutory requirement that an applicant prove that he has not been on welfare for a given period of time before he can be naturalized.

103. The Fifth Amendment, affecting Congress, has no Equal Protection Clatsc. The Due Process Clause of that amendment, however, has been held to incorporate the re* quirements of the Equal Protection Clause of the Fourteenth Amendment. Sce Bolling v. Sharpe, 347 U.S. 497, 500 (1954); Hurd v. Hodge, 334 U.S. 24, 35 (1948). See also Michelman, On Protecting the Poor Through the Fourteenth Amendment, 83 HARv. L. REv. 7, 17 n.25 (1969); Harvith, Federal Equal Protection and Welfore Assistance, 91 ALBANY L. REv. 210 (1967); Henderson v. United States, 231 F. Supp. 177 (N.D. Calif. 1964). Thus the due process rights of aliens include equal protection rights.

104. Little has been written concerning the method of determining which purposes are legitimate. The literature that does exist includes: Developments in the Law-Equal Protection, 82 HARv. L. REv. 1065 (1969) [hereinafter cited as Equal Protection]; H. M.

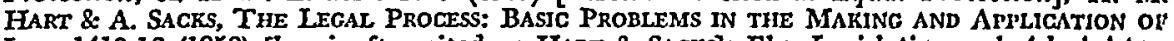
LAW 1410-16 (1958) [hereinafter cited as HART \& SACKs]; Ely, Legislative and Administrative Motivation in Constitutional Law, 79 YALE L.J. I205 (1970). 
confront the question directly. ${ }^{105}$ However, each of the involuntary status classifications mentioned above seems most likely justified, if at all, under one or more of the following three "legitimate puposes":103

(1) To limit naturalization to those resident aliens who are loyal to the United States and who possess good moral character. ${ }^{107}$

(2) To limit naturalization to those resident aliens who are capable of functioning as citizens; that is, those who are competent to participate in the social and political processes. ${ }^{108}$

(3) To conserve the nation's economic, natural, and social resources. ${ }^{109}$

\section{B. Applicable Equal Protection Doctrine}

Under traditional equal protection doctrine, government classifications are invalid only if they are not "rationally related" to a valid government purpose. ${ }^{110}$ As will be demonstrated, some provisions of the naturalization statute and some reported INS practices fail to meet

105. As for an analysis of "legitimate" purposes, it seems clear that a law intended solely to discriminate against a certain class of persons should be considered invalid by reason of an "illegitimate" purpose. That is, some classifications are unacceptable, not because they are not rationally related to the purpose of the statute, but because that very purpose is illegitimate. Equal Protection, stipra note 104, at 1081 . See Ely, supra note 104, at 1224. The most precise criterion of legitimacy that has been suggested is that the purpose be related to improving the general welfare. Equal Protection, supra note 104 , at 1081 . Although it has been demonstrated that such a broad standard has, in certain cases, been rejected (at Ieast implicitly) by the Supreme Court (see discussion of Reynolds v. Sims, 377 U.S. 533 (1964), in Ely, supra note 104, at 1227), it will be adopted for purposes of the present discussion, thus giving vide scope to the naturalization power. But see p. 797 infra.

In attempting to ascertain the "actual" purpose of a particular statutory provision or administrative practice, there are again no hard and fast rules. Generally, the technique seems to be to infer the "probable" purpose(s) of the legislature (Equal Prolection, supra note 104 , at 1078 ) by considering the language of the statute and its legislative history, prior legislation, accompanying legislation, and "general knowledge" concerning the problems of the subject area to which the statute pertains. HARr \& SAchs, supra note 104, at 1341 suggests this technique. But see discussion of Smith v. Cahoon, 283 US. 553 (1931), to the effect that courts sometimes adopt a different technique, in Ely, supra note 104, at 1225-6.

106. These purposes were derived through a combination of the "public welfare" test of legitimacy and the "most likely inference" method of determining probable purpose. Sources consulted on the latter question include immigration and nationality statutes, congressional reports, and judicial opinions.

107. See \& U.S.C. \$\$ 1101(f), 1182(a)(13), 1251, 1427 (1964). See also In te Nosen, 49 F.2d 817, 818 (D. Wash. 1931); Luria v. United States, 231 U.S. 9, 22-3 (1913); In re Taran, 52 F. Supp. 535, 538-40 (D. Minn. 1943); United States v. Gerstein, 284 IIl. 174, 119 N.E. 922 (1918). Cf. In re Capozzi, 160 Misc. 200, 202-03, 289 N.Y.S. 869, 872 (1936).

108. See 8 U.S.C. $\$ \S 1182,1423$ (1964); H.R. Rep. No. 1365, 82d Cong., 2d Sess. (1952) reprinted in 1952 U.S. Code CoNc. \& ADar. News 1653, 1736. See also speech of Rep. Wood, supra note 95.

109. See 8 U.S.C. $\$ \$ 1182(a)(7),(14),(15), 1251(a)(3)$ (1964). See also Ex parle Fragoco, I1 F2d 988 (S.D. Cal. 1926); United States ex rel. NIarkin v. Cumn, 9 Fnd 900 (2d Cir. 1925); Ex parte Rokiyi Tombara, 292 F. 764 (W.D. Wash. 1923); Ex parte N(itchell, 250 F. 229 (N.D.N.Y. 1919).

110. Iindsily v. Natural Carbonic Gas Co., 220 U.S. 61, 78 (1911). See generally Equal Protection, stepra note 104, at 1076-87. 
even this lenient test. Others, however, do meet the rationality test. These latter practices and provisions are, therefore, valid-unless it is appropriate to employ the more stringent "compelling state interest" test $^{111}$ which the Supreme Court has deemed appropriate: (1) if a classification is "suspect," that is, if it discriminates against certain disadvantaged minority groups; or (2) if a classification infringes upon a person's "fundamental interests."

Since resident aliens are totally barred from the political process, alienage is arguably a suspect classification. ${ }^{112}$ It does not necessarily follow, however, that a strict standard of review is required across the board in deportation and naturalization cases. ${ }^{113}$ The reason is that in such cases aliens as a group are not the objects of discrimination. Rather, naturalization and deportation laws necessarily discriminate among aliens on the basis of other, presumably non-suspect, criteria. ${ }^{114}$ This situation, discrimination within rather than against an arguably suspect group, is unique, since in other contexts the very identification of a group to discriminate within would constitute discrimination against that group. ${ }^{115}$ As a matter of judicial policy, it might seem that, in this unique situation, the fact which makes alienage an arguably suspect classification-the complete absence of resident aliens from the political process-should also require review more strict than the rationality

111. The compelling state interest test is, in essence, an interest balancing test, It en* tails a determination of whether the government interests furthered by certain lecislation or the individual interests detrimentally affected are more weighty. Since in the situations in which the test is employed the individual interests are always "fundamental," see pp. 795.98 infra, the government interest, to prevail, must be "compelling."

112. See Equal Protection, supra note 104, at 1124.

113. Of course, if a naturalization statute employed classifications which werc suspect in themselves, strict review would automatically be triggered as to those classifications. Certainly race, religion, and national origin are suspect classifications for naturallza. tion purposes. Unless necessary to a compelling state interest, then, a statute which denicd naturalization on such a basis would be invalid.

It is, of course, highly unlikely that a compelling state interest could be found, since race, religion, and national origin are clearly irrelevant to the three legitimate congressional purposes set forth above (and most likely to any others which might be postulated). $C f$. Ex parte Mitsuye Endo, 323 U.S. 283, 302 (1944). To contend that such characteristics were related to an applicant's worthiness, or to his mental and physical capabilities to function as a citizen, or that they made him a greater burden on society's resources than other persons, would be to assume that a particular race, religion, or nationality was intrinsically inferior. Since such "invidious" assumptions have con. sistently been rejected by the courts, any attempt to renew pre-1952 restrictions based on such characteristics would be unconstitutional.

114. Since deportation and naturalization statutes discriminate within rather than against an (arguably) suspect group, the cases requiring stringent review of suspect classifications, which concern discrimination against suspect groups, are not on point.

115. For example, a statute which denied a jury trial to "any Black person who is on welfare" would constitute discrimination against both Blacks and poor people. However, deportation and naturalization laws are limited by definition to resident aliens. Thus, a statute denying naturalization to "any resident alien on welfare" discriminates against poor people, but not resident aliens. 
test when government classifications, although non-suspect in themselves, affect only resident aliens. ${ }^{118}$

More importantly, careful scrutiny of classifications for deportation

116. The argument would proceed as follows: One of the major justifications for the rationality test is that "interest balancing"-a decision as to the wisdom of a classificatory scheme-is best left to the political process. The process of determining the merits of a classification, which entails moral and political value choices as vell as decisions concerning the merits of various schools of economic and social science thought, is believed to be better suited to legislatures than to courts. Dandridge v. Williams, 397 U.S. 471,480 (1970). Unless a classification substantially furthers no valid governmental purpose, that is, unless it is irrational, traditional equal protection doctrine requires that judges abstain from substituting their judgments for those of legislators, thereby preserving the integrity of the political processes. Dennis et al. v. United States, 341 U.S. 494 (1951) (Frankfurter, J., concurring); Equal Protection, supra note 104, at 1077 .

Implicit in this justification for the rationality test is the assumption that all group3 concerned are represented in the legislative process. Unless a group has access to the legislature, the presumption of fairness attached to legislative balancing of its interests against the interests of other groups which are represented is not varranted. C/. Kramer v. Union Free School District, 395 U.S. 621, 627 (1969); Harper v. Virginia Board of Elections, 383 U.S. 663, 667 (1966); United States v. Carolene Prod. Co., 304 U.S. 144, 153 n.4. (1938); South Carolina State Highway Dept. v. Barnwcll Bros., 303 US. 177, 184 n.2 (1938). This concern has, of course, been one of the reasons why certain underrepre. sented groups have been identified as suspect classifications, entitled to strict revicw when they are discriminated against, and is why resident aliens, who, lacking the franchise, obviously are totally barred from the legislatures, arguably constitute such a suspect category.

It is submitted that this same concern requires a test more stringent than mtionality in cases of classifications for deportation and naturalization purposcs, which uniquely concern discrimination within an arguably suspect group. Without attcmpting cmpirieal proof, two assumptions seem reasonable. First, even if an entire group is not being discriminated against, members of many groups will likely be concerned with ensuring that distinctions among group members are made fairly. If the group as a whole is repre. sented in the political process, that concern is likely to be expressed through political action. If the group is not represented, however, as aliens are not, it is difficult for members to pressure legislators to ensure the fairness of intra-group distinctions. And second, it is unlikely that citizens with characteristics which would cause them to be discriminated against were they aliens will be quick to assert their political influence on behalf of resident aliens with such characteristics. That is, even if classifiction "alpha" is not normally suspect because citizen-alphas are fully represented in the political process, it is not clear that citizen-alphas will feel sufficiently identified with alicn-alphss, or sufficiently threatened by discrimination against alien-alphas, to bring their infuence to bear on the aliens' behalf. Certainly, whatever action they might take is likely to be less strong than if they themselves were the objects of discrimination.

For both of the above reasons, in short, classifications concerning persons not represented in the political process, even if persons who are represented share the relciunt characteristics, are not entitled to the normal presumption of fairness. In the process of legislative interest balancing, there is little guarantee that those persons interests will have been fairly weighed. Thus, a court, faced with the unique problem of determining the proper standard of review for classifications discriminating within an arguably suspect group, might well, as a matter of policy, apply a test more stringent than mere rationality:

This entire argument, of course, is made subject to the following caveat: In the usual situation in which the courts have found classifications to be suspect, the group favored by legislation has been represented fully in the politial process and the disfirored group has not. The fear has been that the favored group would use its political influence to discriminate against the powerless unfavored group. In the context of the present argument, by contrast, neither the favored nor the unfavored group is represented. Rather, the problem is that a group which is represented (citizens) is discriminating within a group which is not (resident aliens). The fear is that the represented group will use its influence to serve only its interests, ignoring the interests of the unreprecented group.

The caveat is that the above fear rests on the value judgment, made earlier, that the interests of resident aliens are of substantial weight, and should limit the ability of citizens to serve their own interests. 
and naturalization purposes should be required because they affect the fundamental interests of resident aliens: naturalization is a prerequisite for the franchise; and deportation revokes the right to reside in the United States. Both the vote and residence must be considered fundamental interests within the context of equal protection doctrine.

As for the vote, the Supreme Court held in Harper v. Virginia Board of Elections that a citizen's interest in voting is fundamental, and that "classifications which might invade or restrain [it] . . . must be carefully confined"117 through judicial scrutiny more stringent than the rationality test. Harper therefore requires the conclusion that a resident alien's interest in voting is likewise fundamental, unless there is a difference between the citizen's interest in exercising his right to vote and the resident alien's interest in gaining the right to vote.

It seems clear that, in terms of importance to the individual concerned, ${ }^{118}$ there is no difference. As noted previously, all residents, citizens and aliens alike, are equally affected by government policy decisions and equally obligated to obey all laws. All residents, therefore, citizens and aliens alike, would seem to have an equal personal stake in being able to influence, through the vote, the policies and laws which affect them. If the citizen's personal stake is deemed fundamental, then, it would seem, so must the alien's. 110

The resident alien's interest in the deportation process, too, should be considered fundamental. Deportation, which has been recognized by courts as the equivalent of banishment or exile, ${ }^{120}$ entails drastic personal consequences. At stake for the resident alien is his ability to remain in the nation of which he is a permanent resident, with his

117. 383 U.S. at 670 .

118. The proper focus for determining whether an interest is fundamental is its im. portance to the individual. See Shapiro v. Thompson, 394 U.S. 618 (1969); Griffin v. Illinois, 351 U.S. 12 (1956) (Black, J.); Equal Protection, supra note 104, at 112.

119. Nor should it matter that, in terms of the vote, the citizen's interest is in cxercising a "right," while the alien's is in gaining a "privilege." Whatever utility the right/ privilege distinction may have in other contexts, it is clear that it is irrelevant to thic magnitude of the affected person's interest. The personal interest is to be able to influ. ence the laws; and the personal gains which are likely to result from that ability, as well as the personal losses which are likely to result from its absence, are not changed by labelling the ability a privilege rather than a right. See Griffin v. Illinois, 351 U.S. at 19.

Of course, the resident alien's fundamental interest in gaining the vote is to some extetit entwined with his interest in avoiding deportation which will be argued below to be
fundamental. That is, the argument that the resident alien has a fundamental intercst in participating in the formation of the laws which he has to obey to some cxtent alssumes that he has a fundamental interest in remaining in the jurisdiction, subject to the laws which are made.

120. Fong Haw Tan v. Phelan, 333 U.S. 6, 10 (1948): Carmichacl v. Delancy, 170 F.2d 239, 245, (9th Cir. 1948). In Trop v. Dulles, 356 U.S. 86 (1957), the Supreme Court held that expatriation of citizens, which entails deportation, is a cruel and unusuat pun. ishment. 
home, family, friends, and business, ${ }^{121}$ as well as his interest in avoiding stigmatization as an outcast. These personal interests are virtually identical to the interests of a defendant in the criminal process, who similarly attempts to avoid stigmatization and separation from personal and business associations due to imprisonment. ${ }^{102}$

The interest of a defendant in the criminal process has, of course, been deemed "fundamental" by the Supreme Court, at least implicitly;:123 and the stringent equal protection test has been afforded such persons. Since the interest of a resident alien in the deportation process is virtually identical, ${ }^{124}$ it would seem that government action imposing the consequences of deportation must also be subject to the stringent equal protection test.

This argument is, of course, subject to the caveat that, since the Supreme Court in identifying fundamental interests has apparently proceeded on an ad hoc basis, ${ }^{125}$ without defining limiting principles, arguments analogizing personal interests which the Court has not yet considered to personal interests which it has deemed fundamental are, as a predictive matter, uncertain. Nevertheless, unless each case in which a fundamental interest has been identified is considered per se unique, or unless the Court in identifying fundamental interests is considered to be acting irrationally, arguments comparing newly considered interests to fundamental interests can be attempted. The chance of success would seem greatest when the newly considered interests are virtually identical with interests which have been identified as fundamental. That, it is submitted, is the case both in naturalization cases, which like Harper concern the ability to vote, and in deportation cases, which, like the cases affording strict review to criminal defendants, concern affirmative government action stigmatizing an individual and separating him from personal and business associations. This Note, therefore, will proceed on the assumption that the more stringent equal

121. It must be remembered that many resident aliens have spent much of their lives as permanent members of the American population, often entering the nation as a child. Thus, all their personal ties may be in the United States; and, if deported they would be strangers in their native land.

122. Indeed, the consequences of deportation are likely to be cren more serious than the consequences of imprisonment. After a prisoner has served his jail term, he is free to return to the community; but, as a practical matter, it is virtually impossible for a resident alien who has been deported to obtain a second immigrant risa.

123. See Griffin v. Illinois, 351 U.S. 12 (1956); Equal Protection, supra note 104, at 1127.

124. There is some question as to whether the scope of Grifin includes appenls from sentences imposing a fine, rather than a prison term. See, e.g., State v. Borst, 278 Mtinn. 388, 154 N.TW. 2d 888 (1967); Y. KAMnSAR, W. LAFAVE, J. IsRaEL, L. HALL, AroderN CruasINAL PROCEDURE 122 (1969). Whether or not Griffin can be limited in that manner, it is clear that the case itself was concerned with the penalty of imprisonment.

125. Equal Protection, supra note 104, at 1130 . 
protection test is required in deportation and naturalization cases. If a statutory provision or administrative practice is unconstitutional under the rationality test, that test will be employed. If the rationality test is met, however, provisions and practices will be considered in light of the compelling state interest test.

\section{Moral Character}

With respect to the first of the three legislative purposes mentioned above, that of choosing citizens with good moral character, it would seem that the rationality test requires classifications to be based only on voluntary acts or omissions. Only behavior which the resident alien can consciously control would seem to be "rationally related" to a judgment concerning his character. ${ }^{120}$

It might be argued, however, that some seemingly involuntary statuses are so closely associated with voluntary actions that they are, in effect, voluntary statuses, and hence probative of character. The statutory provision precluding naturalization of "habitual drunkards" raises this issue. ${ }^{127}$ In Powell $v$. Texas, ${ }^{128}$ the Supreme Court upheld, by a vote of 4-1-4, the validity of a Texas statute outlawing public drunkenness. The opinion of the four Justices who voted together to uphold the law can be read as holding that it is permissible to assume that drunkenness is acquired through the voluntary act of drinking alcoholic

126. First, if character is vicwed as a measure of ability to choose between courses of action with different moral connotations, behavior which a person cannot consciously control is not probative. That is, since involuntary behavior is by definition unaffected by a person's value structure, it is irrelevant to a determination of that structure.

Second, an analysis of the cases interpreting good moral character requirements (in naturalization and other contexts) reveals that judges have considered only conduct, as opposed to status. See Repouille v. United States, 165 F.2d 152, 153 (2d Cir. 1917); In 48 Bespatow, 100 F. Supp. 44, 45 (W.D. Pa. 1951); In re Markiewicz, 90 F. Supp. 191, 194, 195 (W.D. Pa. 1950); United States v. Cloutier, 87 F. Supp. 848, 852 (E.D. Mich. 1949); Petition of De Leo, 75 F. Supp. 896, 900 (W.D. Pa. 1948); In re Mogus, 73 F. Supp. 1b6, 152, 153 (W.D. Pa. 1947); In re Paoli, 49 F. Supp. 128, 130, 131 (N.D. Calif. 1943); In re Spenser, 22 F. Cas. 921 (No. 13,234) (C.C.D. Ore. 1878).

Finally, it would seem that classifications relevant to moral character must be limitcd to voluntary actions in order to guard against discriminatory purposes. If Congress is allowed to bar naturalization for resident aliens with statuses which are neither voluntary, nor incapacitating (second purpose), nor a drain on the nation's social or cconomic resources (third purpose), then the legislators would be free to find a class of persons of bad character simply because they believed them to be inferior or unworthy. Allowing Congress the freedom to act on the basis of such Heliefs, however, would be nothing less than allowing them to renew historic discriminations on the basis of classifications stich as race, sex, or nationality. That is, if Congress can act against a class merely because it believes its members to be of bad character, without indicating a reasonabla basis for the belief, there is no principle by which a court can determine whether they are dis. criminating for discrimination's sake. Indeed, it could be argued that congressional action based on a mere belief in a class' bad character or inferiority can be nothing else tluan discrimination for discrimination's sake.

127. The congressional belief that alcoholism is indicative of character is obvious, as the prohibition is located in 8 U.S.C. 1101(f) (194) which defines "good moral character."

128. 392 U.S. 514 (1968). 
beverages, and is generally known to be a risk inherent in that act. ${ }^{129}$ If their opinion is considered the law of the case, then the statutory provision concerning drunkenness is valid under the rationality test; for the status of drunkenness, so viewed, becomes, in essence, a "voluntary status." Accepting their premise, it seems clear that the voluntary status of drunkenness would be probative of bad character, as defined by prevailing social standards; and, since it can in the opinion of the four Justices be made a crime, the provision would not be invalid under the doctrine of unconstitutional conditions. ${ }^{130}$

Justice White, in the "swing opinion," assumed that although it might be impermissible to assume that drunkenness is voluntarily acquired, the state of being drunk in public is voluntary. ${ }^{131}$ If his opinion is considered the law of the case, ${ }^{132}$ then the statutory provision denying citizenship to all habitual drunkards, not just those whose drunkenness is manifest in public, is unconstitutional. That is, the statutory provision is, under Justice White's assumptions, insufficiently related to any voluntary act to be probative of unworth. ${ }^{103}$

The application of the rationality test to the provision denying naturalization to drunkards, is, then, unclear, because of the ambiguity of the Powell decision. There is no such uncertainty, however, with respect to the provision denying naturalization to resident aliens who are, or who were at any time after entry, drug addicts. The Supreme Court has held that drug addiction can be acquired in an entirely innocent manner. ${ }^{134}$ Therefore, although addiction can of course be acquired through a voluntary criminal act, it is not necessarily related to such an act, and hence not determinative of bad character. ${ }^{135}$ The statutory provision, which fails to discriminate between involuntary

129. Id. at 522-23.

130. Of course, the fact that an act is criminal is usually indicative of society's belief that it demonstrates the actor's unworth. It is not clear, however, in light of the manifold functions of the criminal law, that this is alwajs the case. Especially with respect to crimes of "absolute liability," the fact that an individual has committed a crime may" not, under all circumstances, be sufficiently probative of unvorth to be conclusive.

131. The defendant, knowing himself to be an alcoholic could have taken precautions against being found drunk in a public place.

132. Counting his vote, five Justices believed that alcoholism per se cannot be presumed voluntary.

133. This discussion has assumed that the criminal law standard of voluntariness is, at least in this situation, applicable in the naturalization context. That is most likely a reasonable assumption, since the question of voluntariness in Powell scems to be "Factual," turning on empirical evidence.

134. See Robinson v. California, 370 U.S. 660, 667 (1962); Linder v. United States, 268 U.S. 5, 18 (1925).

135. Of course, a regulation denying citizenship and/or deporting those who use drug 3 illegally would be acceptable under the rationality test. 
and criminal addicts, is an overinclusive classification with respect to moral character and invalid under the Equal Protection Clause. ${ }^{130}$

Although the statutory provisions denying naturalization to drunkards and addicts are of doubtful validity under the rationality test, many classifications related to moral character are clearly valid if only that test is employed. That is, under the rationality test, any voluntary act or omission which is morally disfavored under prevailing community standards, including virtually every act which is or could be made criminal, ${ }^{137}$ could validly be made grounds for denial of naturalization. If the more stringent equal protection test is employed, how. ever, the government's interest in denying naturalization to persons who had committed certain morally disfavored acts would have to be weighed against the "fundamental" interest of the resident alien in obtaining citizenship. A court would have to determine which acts are indicative of moral character sufficiently poor so that the government interest in denying naturalization is "compelling."

Without attempting to decide specific cases, it should be noted that, under this test, an act might be indicative of moral character sufficiently poor to deny naturalization even though the same act would be insufficient grounds for denying the franchise to citizens. The reason is that, although the individual interests at stake in both naturalization and citizen-voting cases are fundamental, the government has more at stake in naturalization than in citizen-voting cases.

Although the Supreme Court has not recently ruled on the issue, the government's interest in denying the vote to some citizens with very bad character, for example, convicted felons, seems sufficiently "compelling" to prevail over the individual's interest in voting. ${ }^{188}$ "The

136. The statutory provision disqualifying aliens who have spent more than six months in a penal institution (during the five years for which moral character is evaluatcd) is also subject to attack as not rationally related to moral character. The status of being incarcerated is, of course, closely related to voluntary criminal acts and therefore often probative of moral character. But the present provision may distinguish unconstitution. ally among resident aliens who are, based on their voluntary acts, identical in worth. First, in light of the fact that delays in detection, prosecution and appeal vary froin juris. diction to jurisdiction and from case to case, it is possible that two aliens comuitting iden. tical crimes on the same date might complete their prison terms at different times, cven as. suming that their sentences were identical. That assumption, of coursc, is often falsc, especially in light of the possibility that one alien might demand a jury trial and the other "cop a plea" for a reduced sentence. Thus, the involuntary status of incarceration during the five year probationary period is often not a rational means of distinguisling: among applicants on the basis of bad character.

137. Under the unconstitutional conditions argument, it must be remembercd, the act must be unprotected.

138. The government's interest in denying the vote to citizens with very bad character, which in terms of the first purpose defined above includes disloyalty and malevolenee towards the nation, is to protect the political process from the destructive influences of (I) persons who do not have the best interests of the nation in view, and who therefore 
government, of course, has an identical interest in preventing resident aliens with equally bad character from voting. Consequently, the government can clearly deny the vote to a resident alien who fails to meet the character standards which can be required of voting citizens. It does not follow from that government interest alone, however, that the government should be able to deny such a resident alien naturalization. The interest could be adequately served by allowing the person to be naturalized, and then denying him the vote along with other citizens with very bad character.

There is an additional government interest, however, which requires that the government be allowed to deny naturalization to resident aliens with bad character. In addition to denying him the vote, the government has an interest in retaining the ability to deport him. ${ }^{139}$ It was earlier asserted ${ }^{140}$ that the government does not gain much by retaining the ability to deport a resident alien who, during his five year probationary period, has evinced good moral character. With respect to resident aliens of demonstrably poor character, on the other hand, there would seem to be a substantial government interest in protecting society from their presence. Even if the alien had not demonstrated character sufficiently poor for immediate deportation, ${ }^{141}$ his demonstrable character defects, potentially injurious to society, should arguably be sufficient to enable the government to "keep an eye on him"-in effect, to extend his "probationary period" beyond five years.

Since the government loses the ability to deport a resident alien when he is naturalized, the moral character standards which resident aliens must meet to be naturalized can be stricter than those which citizens must meet in order to exercise their right to vote-that is, some acts indicative of poor moral character can be grounds for denying naturalization even though they could not be grounds for denying the vote to citizens. In both naturalization and citizen-voting cases, the fundamental individual interests in voting are of equal weight; and the government interest in denying the vote to persons of bad character is the same in both cases. However, the government interest in retaining the ability to deport adds an additional weight to its side of the balance

might use their votes to deliberately harm the nation, or (2) persons who, through criminal actions, have demonstrated a lack of respect for laws, and who are therefore unfit to participate in their making.

139. Since citizens cannot be deported, Ng Fung Ho v. White, 259 U.S. 276, 280 (1922), naturalization terminates the gorernment's ability to deport.

140. See note 37 supra.

141. This statement, of course, assumes that the interest test is applicable, since under the rationality test Congress could deport an alien for any bad act, without consideration of degree. 
in naturalization cases. Therefore, along a scale of bad moral character, the government interest will become sufficiently compelling to override the individual interest in naturalization cases before it will in citizenvoting cases.

In sum, if the compelling state interest test is employed, naturalization can be denied only when a resident alien's moral character is sufficiently poor so that the government interests in denying the vote and retaining the ability to deport outweigh his fundamental interest in voting. The standard could be more restrictive than in citizen-voting cases, but would be less restrictive than under the rationality test, which would allow disqualification for any act indicative of poor character.

\section{Incapacity}

Some of the statuses discussed above, such as habitual drunkenness and drug addiction, may have such detrimental effects on an individual's physical or mental well-being that he is rendered incapable of normal social functions. If that were the case, the individual could validly be barred from naturalization, under the rationality test, in furtherance of the second legislative purpose postulated above, that of limiting naturalization to resident aliens who are capable of functioning as citizens. Also in furtherance of that purpose, it would seem that restrictions on the basis of age, insanity, retardation, or other severely incapacitating statuses are "rationally related" to the purpose of having capable citizens. ${ }^{142}$ Further, since an individual with such statuses lacks even minimal capabilities needed to function in the social and political processes, he could be validly denied the franchise even if he were a citizen. ${ }^{143}$ The interest test is therefore most likely satisfied, since a compelling state interest is needed to deny a citizen the vote. ${ }^{144}$

142. An understanding of the English language might also be requircd, since, in the absence of a statutory prohibition, states may be able to establish such a requirement for citizen-voters. Cf. Katzenbach v. Morgan, 384 U.S. 641 (1966).

The courts must exercise caution, however, in holding conditions valid under this legislative objective. Especially with regard to physical illness, there is a potential for abuse; and there is need for a careful factual determination that the status is incapacitating.

143. See, e.g., 42 U.S.C.A. \$ 1973bb-1 (Supp. 1971) (denying the vote to citizens under eighteen years old); N.Y. Election Law $\$ 152(6)$ (McKinney 1964) (denying the vote to those judged incompetent or committed to an institution for the care and treatment of the mentally ill or mentally defective).

144. It is possible, however, that the interest test would not be satisfied. The govern. ment interest in protecting the vote from persons lacking minimal capabilitics could be furthered by allowing such persons to be naturalized, but denying the vote to them and to all other citizens with similar statuses. However, the issue is of little consequence, bc. cause most statuses which render a person incapable of voting also preclude an under. standing of the naturalization process. That is, a severely incapacitated person could 
It might be further suggested, however, that Congress can legitimately establish restrictions based on a level of capability above the minimum, that is, above the degree of incapacitation for which citizens can be denied the vote. Thus, in an effort to admit to citizenship only the "cream of the crop" of resident aliens, Congress might limit naturalization to those with above average intelligence, knowledge, and reading and speaking ability. Similarly, it might attempt to bar naturalization to the impoverished, or to drunkards and addicts, on the empirical assumption that they will have below average inclination or ability for civic participation.

Such classifications would probably meet the rationality test, since it is arguably of benefit to the nation to have an informed and intelligent electorate. If an interest test is employed, however, regulations precluding naturalization for aliens with less than a high level of capabilities (but more than minimum capabilities) would almost certainly be invalid. ${ }^{145}$

In sum, under both the rationality and interest tests, resident aliens incapable of normal social functions could be disqualified. Under the rationality test, restrictions requiring a high level of ability would probably be valid; but under the interest test they would be invalid.

\section{E. Social Burden}

With respect to the third legislative purpose postulated above, alleviating social burdens, resident aliens who are sick or impover-

usually be denied naturalization simply because he is unable to make the decisions involved.

145. Under the interest test, standards for denying naturalization on the basis of incapacity would be constitutional only if they could be used as standards for denying the franchise to citizens. Unlike the situation with respect to moral character requirements, see PP. 800-02 supra, there is in the case of incapacity no additional gorernment interest in the naturalization, as opposed to the citizen-roting, context. Putting aside until the next section the question of statuses which are so incapacitating that they render a person a burden on the nation's resources, the government would secm to have no interest at all in retaining the ability to deport a self-supporting person merely because he is less intelligent or in other respects less able than others. Unlike a person with bad character, such a person creates no evil effects which society must guard against. That is, unlike the case of moral character, in which the government has an interest in retaining the ability to deport a person in order to protect society, an interest which is distinct from its interest in denying the person the vote, in the case of maximum apacity requirements there is no government interest in retaining the ability to deport. The only government interest in capacity cases, therefore, is the interest in denying the vote. Since that interest is identical in both naturalization and citizen-yoting cases, and since the individual interest in both cases is fundamental, the interest test requires that no resident alien can be denied naturalization on the basis of incapacity unless a citizen could validly be denied the vote on the same grounds.

Put in that context, it is clear that any attempt to limit naturalization to resident aliens with above average capabilities would be invalid. Although minimum capabilities may be required before a citizen can vote, it hardly need be stated that a requirement of above average intelligence or ability would be struck down. 
ished ${ }^{148}$ are clearly burdens on the nation's economic and natural resources. ${ }^{147}$ However, the denial of citizenship to resident aliens who are diseased or impoverished, by itself, alleviates a burden on the nation's resources only if it is permissible for the state to discriminate against resident aliens when allocating resources to those persons in the population who are poor or sick. That is, if resident aliens are entitled to share in the nation's resources so long as they remain residents, it is residence, rather than citizenship, which renders the diseased or impoverished resident alien a social burden.

There is little doubt that a state, within limits imposed by the Interstate Commerce Clause, can protect its resources from consumption by classes of persons who do not make a financial or material contribution to the state. ${ }^{148}$ The class of aliens who are state residents, however, makes the same financial and material contribution to the state as do state citizens. ${ }^{149}$ Both classes of residents-aliens and citizens-contribute directly to the state through taxes; and both classes aid in economic development through employment and investment. Because they undertake identical financial commitments to the state, resident aliens and state citizens must be considered "similarly situated" with respect to public programs, facilities, and property. ${ }^{160}$ Although denying public aid to resident aliens would no doubt conserve state resources, ${ }^{151}$ it would do so through the "irrational" means of discriminating among state residents, all of whom are equally entitled to use state resources. ${ }^{162}$

This conclusion seems compelled by two Supreme Court decisions. In Takahashi v. Fish and Game Commission, the Court invalidated a California statute which prohibited the issuance of fishing licenses to

146. If restricting naturalization on the basis of poverty or non-incapacitating disease can be justified, it must be under the third purpose. Since such statuses are in the cyes of the law involuntary, they are not rationally determinative of an applicant's worth.

147. It is costly in terms of scarce medical facilities and manpower to care for the diseased, even if they can afford to pay for medical services. Persons with contagious dis. eases spread harm to others, multiplying the economic burden. Persons who are impove erished and on welfare live off the fruits of the labor of others. And neither the discased nor the impoverished are likely to contribute substantially to the nation's cconomy through gainful employment.

148. Cities Service Gas Co. v. Peerless Oil and Gas Co., 340 U.S. 179 (1950); Hudson Water Co. v. McCarter, 209 U.S. 349 (1908).

149. A state citizen is merely a national citizen who is a state resident. U.S. CoNST, amend. XIV, \& 1. See Hammerstein v. Lyne, 200 Fed. 165, 169 (1912).

150. See Note, 17 N.Y.U. L. Q. REv. 242, $245-46$ (1940).

151. It would also save money to deny welfare to all Blacks, women, etc. Yet, those discriminations would clearly not be allowable merely to further a conservative fiscal policy.

152. Of course, if the earlier suggestion that alienage is a suspect classification is accepted, see pp. 79495 supra, an interest test could alternatively be used to find such dis. crimination illegal. 
resident aliens who were ineligible for naturalization. ${ }^{108}$ In Shapiro $v$. Thompson, the Justices invalidated a state statute which discriminated against new (in favor of old) residents in allocating welfare payments. ${ }^{164}$ Both cases proceed upon the assumption that present residence, rather than citizenship or any other status, entitles a person to a full share of the state's resources. ${ }^{155}$

Since it is not permissible for a state to discriminate against resident aliens when allocating public resources, no economic burden would be relieved by denying citizenship to sick or poor aliens who thereafter remain residents. In other words, denying naturalization to aliens who are sick or poor is "rationally related" to the third legislative purpose only if such a status is grounds for deportation as well as denial of naturalization. The issue, then, is whether Congress could validly require the deportation of such resident aliens.

As a corollary to its power to establish requirements for immigration, it would seem that Congress can require deportation of resident aliens who entered the country in violation of valid entry requirements. ${ }^{165}$ Specifically, if the statute regulating initial entry contains restrictions

153. 394 U.S. 410, 421 (1948). The Court initially considered the ase under the rationale of Truax v. Raich, 289 U.S. 33 (1915), which held that the federal government, by lawfully admitting an alien into the nation, grants him the right to live and vork in any state. That right, Traux held, cannot be limited by state legislation-unless the state can show a "special public interest." In Takahashi, California contended that its property interest in fish within three miles of its coast was "special." The Supreme Court rejected that contention. It stated, first, that since the fish were migratory, they were not the property of California. Next, the Court held that eren if the fish were a state resource, and the state therefore entitled to conserve them, they must be conseried for the benefit of all lawful residents of the state, citizens and aliens alike. $33 \pm$ U.S. at 419-22.

154. 394 U.S. 618 (1969). The Court commented: "We have difficulty seeing how longterm residents who qualify for welfare are making a greater present contribution to the State in taxes than indigent residents who have recently arrived." Id. at 632. See also, Note, Residence Requirements After Shapiro v. Thompson, 70 Coluar. L. REv. I31 (1970), "[The] justification for denying welfare benefits to aliens is cren less substantial than those offered and rejected in Shapiro to justify the denial of these bencfits to indigent citizens who have recently entered the state. The alien may have lived in the community for years, paid taxes, and served in the Amerian armed forces; yet, if he is blinded or becomes aged, there is no assistance forthcoming from the state." Id. at 14l. The Co. lumbia Note suggests that, although the states cannot discriminate against resident aliens in allocating public funds in the absence of federal authorization, Congress might validly authorize such treatment. Id. at $143-44$. Such a suggestion would seem to ignore the fact that the federal government is also bound by the Equal Protcction Clause, see note 103 supra.

155. In Purdy \& Fitzpatrick v. State, 71 Cal. 2d 566, 581, 456 P.2d 645, 656, 79 Cal. Rptr. 77, 88 (1969), the California Supreme Court recognized the lesson of these cases and explicitly denied the state the power to favor its own citizens in the disbursement of public funds. The United States Supreme Court, this term, has agreed to rule on the question of state welfare laws disqualifying resident aliens, since three-judge district courts in Pennsylvania and Arizona have invalidated such statutes. Richardson $v$. Graham, 313 F. Supp. 34 (D. Ariz. 1970), 39 U.S.L.W. 3255 (U.S. Dec. 14, 1970), Sailer v. Leger, 39 U.S.L.W. 3255 (U.S. Dec. 14, 1970).

156. As noted above, see p. 775 supra, Congress arguably has unfettered power over an alien's initial entry. 
against aliens who are diseased or impoverished, ${ }^{107}$ a resident alien can be deported if, at the time of entry, he had a disqualifying status. The grounds for deportation would be, in essence, illegal entry. ${ }^{168}$

It would be a far different matter, however, to hold that Congress can require deportation of an alien who had entered legally, but who acquired a burdensome status after entry. ${ }^{150}$ Under the rationality test, deportation of such persons would probably be valid, since the purpose of conserving resources is legitimate and the discrimination among resident aliens on the basis of burdensome statuses rationally furthers the purpose. However, under the compelling state interest test, the result is different.

As for the status of poverty, an analogy can be made to the Supreme Court's decision in Griffin v. Illinois, ${ }^{100}$ which invalidated a state system of appellate review of criminal convictions in which the availability of an appeal was conditioned on payment for a stenographic transcript of the trial. Although the Court recognized that an appeal might be a privilege rather than a right-that is, that the state might constitutionally deny an appeal to all convicted defendants-it held that, once the state made provision for an appeal in some cases, it could not deny it to defendants unable to afford a transcript. ${ }^{101}$

Griffin, in which the Court apparently applied the interest test, was cited earlier to support the argument that the individual interests at stake in the deportation process are "fundamental." The reason was the virtual identity between the consequences of criminal conviction and deporta-

157. See 8 U.S.C. 1182(a)(1), (2), (4), (5), (6), (15) (1964).

158. That, of course, is not to suggest that such a policy would be wise-only that it would be constitutional.

159. If the government attempted to deport such persons merely because they were on the welfare rolls or in the hospitals, then the law would clearly be invalid. $\Lambda \mathrm{s}$ noted above, resident aliens, so long as they have resident status, have a constitutional right to an equal share in public programs and resources. Even though there is no right to obtain a certain status, such as residence, it should be clear that the status cannot be revoked merely because a person exercised a constitutional right inherent in the status. Cf. Gardner v. Broderick, 392 U.S. 273 (1968), in which the Supreme Court held that although a policeman had no "right" to public employment, he cannot be fired mercly because he invoked the privilege against self-incrimination before a grand jury. Similarly, it would seem that a resident alien could not lose his "privilege" (residence) mercly bc. cause he invoked the privilege against self-incrimination-or otherwise accepted the ben. efits of American residency.

160. 351 U.S. 12 (1956).

161. Id. at 18. See also Williams v. Illinois, 399 U.S. 235 (1970) (forbidding Illinois from keeping an indigent in jail beyond the maximum period fixed by statute for the crime in order to "work off" a fine); Douglas v. California, 372 U.S. 353 (1963) (holding that an indigent has a right to counsel on appeal); The Supreme Court, 1969 Tcrm, 84 HARv. L. REv. 30, 46 (1970); Note, Adequate Appellate Review for Indigents: A Judicial Blend of Adequate Transcript and Effective Counsel, 52 IowA L. REv. 902 (1967); Comment, Equal Protection and the Use of Fines as Penalties for Criminal of * fences, 1966 UNrv. OF IrL. LAW FORUM 460. 
tion-both involve stigmatization and separation from personal associations. Since Griffin held that the consequences of conviction cannot be imposed on the basis of classifications concerning wealth, and since the consequences of deportation are virtually identical to those of conviction, it would seem that deportation likewise cannot be imposed on the basis of poverty. That is, whether or not government has an affirmative duty to alleviate the hardships inherent in the status of poverty, Griffin makes it clear that the government cannot take affirmative action-whether imprisonment or deportation-imposing, through criteria based on wealth, the additional hardship of separation from personal associations. ${ }^{162}$

In sum, the rationality test is not met by the denial of naturalization to resident aliens who are impoverished. The denial of citizenship would alleviate no economic burden because: resident aliens are entitled to a fair share of the nation's resources, and resident aliens cannot be deported on the basis of poverty. ${ }^{103}$

The same line of argument would appear generally to preclude deportation of resident aliens on the basis of burdensome statuses other than poverty. As for deportation of diseased resident aliens, ${ }^{10 s}$ it is clear that if the government purpose were viewed as conservation of

162. Further, the case for the unconstitutionality of a law deporting resident aliens on the basis of poverty is even more compelling than the case against the law at issue in Griffin, for, in the case of such a law, Congress could achieve its purposes through means less harmful to constitutionally protected interests. Without deporting impoverished resident aliens, Congress could substantially protect the nation against "imported parasites" and foster economic development by regulating initial entry of non-resident aliens. See note 157 supra. That is, it could issue immigrant visas only to persons who vere healthy and, if not wealthy, employable. There is little necessity, in other words, to impose cxtraordinary hardships on those aliens who enter legally but who, perhaps through no frult of their own, "fall on hard times" once within this country.

It could be alternatively argued that, with respect to granting citizenship (which cntails granting the right to vote), economic purposes are not legitimate. See Harper v. Virginia Board of Elections, 383 U.S. 663 (1966) (invalidating a poll tax qualification for voting), in which the Court stated: "Wealth, like race, creed or color is not germane to one's ability to participate intelligently in the electoral process. Lines drawn on the basis of wealth and property, like those of race, are traditionally disfavored." Id. at 668. See also Kramer v. Union School District, 395 U.S. 621 (1969); Ely's discussion of Reynolds v. Sims, supra note 104, at 1227; Note, Ownership of Land as a Prerequisite to the Right to Vote: Equal or Un. equal Protection, 117 U. of PA. L. Rev. 594 (1969). Thus, although it has been assumed that economic purposes are legitimate, it may be that in some contexts they are invalid.

163. Of course, although this conclusion is put in terms of the rationality test, the second point on which it is based was deduced through the interest test.

If the argument that the naturalization process concerns fundamental individual interests is accepted, the interest test could be employed at the outset, and an assertion made that the state interest in denying naturalization to poor people is not "compelling." The more involved argument was made above because it more closely parallels the case law.

164. As was the case with poverty, the denial of naturalization, by itsclf, would not be a rational means to conserve public funds or protect the health of citizens-since it is residence rather than citizenship which causes the burden. See p. 804 supro. The proper focus, therefore, is whether such persons could be deported. 
economic resources (the disease being viewed as an economic burden), the analysis would be identical to the one above. Disease would, in effect, be translated into a wealth classification.

A law requiring deportation of resident aliens with contagious diseases, however, might be viewed as a public health measure, serving the additional government interest of protecting the health of other members of the population. Notions of fairness aside, ${ }^{105}$ there is certainly a valid government interest in preventing physical suffering among citizens; and deportation of resident aliens with contagious diseases would obviously further that interest. ${ }^{106}$ As noted in a previous section, ${ }^{107}$ however, that governmental interest can be translated into an economic interest-the interest in avoiding the expense entailed in isolating the alien in a hospital until the disease has run its course. That, of course, is the method the government employs when citizens contract dangerous contagious diseases. The government interest in deporting rather than isolating can only be that the former method is cheaper.

The question with respect to contagious diseases becomes, then, whether the government interest in saving expenditures outweighs the fundamental individual interest in avoiding the consequences of deportation. Although the classification is not based on wealth, Griffin would seem to be relevant again, for both the individual and the government interests at stake in the contagious disease situation are the same as those at stake in Griffin. The individual interest is in avoiding permanent separation from personal associations; the government interest is in reducing expenditures. ${ }^{168}$ In Griffin, when the interest test was employed, the former was found to outweigh the latter. It would seem, then, that when those same interests are weighed in the deportation context, the individual interest should likewise prevail..$^{100}$

165. Since the immigration law can and does provide that only healthy alicns can enter the United States, the disease was contracted within the United States, very likely from a citizen.

166. Of course, if the alien no longer had the contagious disease, no state purpose would be served by deportation.

167. See p. 777 supra.

168. The interest of the state of Illinois in Griffin was to avoid the expense of pro. viding indigents with free copies of their trial transcripts.

169. This argument does not imply that resident aliens can never be deported-that the government is powerless, for example, to deport aliens who have demonstrated themselves to be of bad moral character through serious anti-social acts. Although the objectives of deterring anti-social conduct and removing offenders from socicty could be accomplished through the criminal process, deportation does not rest solely on the government interest in reducing the costs of its court and prison systems. Rather, since such a resident alien has breached the duties and obligations which he owes the United States, the government is no longer required to afford him protection. 
Thus, as was the case with poverty, the rationality test is not met by the denial of naturalization to resident aliens who are diseased, even if the diseases are contagious. The denial of citizenship would alleviate no burden, because resident aliens are entitled to a fair share of medical resources, and resident aliens cannot be deported on the basis of disease. ${ }^{170}$

\section{Conclusion}

In a 1954 opinion upholding the deportation of a resident alien, who had resided in the United States since 1918, on the grounds of past membership in the Communist Party, Justice Frankfurter wrote:

In light of the expansion of the concept of substantive due process as a limitation upon all powers of Congress, ... much could be said for the view, were we writing on a clean slate, that the Due Process Clause qualifies the scope of political discretion heretofore recognized as belonging to Congress in regulating the entry and deportation of aliens .... But the slate is not clean. As to the extent of the power of Congress under review, there is not merely a "page of history;" . . but a whole volume .... [T] [hat the formulation of these policies is entrusted exclusively to Congress has become about as firmly imbedded in the legislative and judicial tissues of our body politic as any aspect of our government.171

Although the doctrine of stare decisis has been central in the development of American law, it cannot be applied mechanically when to do so would merely perpetuate injustice and unwise judicial policy. ${ }^{172}$ The "volume of history" of which Justice Frankfurter wrote is replete with

170. A final class of "socially burdensome" statuses which might be mentioned is those which, even though involuntary, might be viewed as a danger to the "moral fiber" of the nation. Two such statuses might be drumkenness and drug addiction. As noted above, both can occur voluntarily, and when they do can be rational grounds for denying naturalization on the basis of poor moral character. Even when they occur involuntarily. however, some might view them as a danger to the community. Specifically, some might contend that a drunkard or addict, even if his status is involuntary, might have an ad. verse moral impact on society by inducing others, through his cxample, to voluntarily acquire his status. Once again the focus is deportation, since it is clearly residence, rather than citizenship, which creates the burden.

Employing the interest test, it would seem that the government's interest in deporting a resident alien to avoid the possibility that, through his involuntary cxample, he might induce others to acquire his status is minimal, for presumably he has a right to voluntarily urge upon others the pleasures of his status. That is, since an addict, for example, would have a first amendment right to inform others that it "feels good to be high." the government loses little when it is unable to deport him for communicating the same message by "looking like he feels good" when he is high. And, to the extent that the state does deem it important to prevent such communication, it could simply treat the alien's condition as it does those of its citizens.

171. Galvan v. Press, 347 U.S. 522, $530-1$ (1954).

172. Cf. Moragne v. States Marine Lines, Inc, 398 U.S. 375 (1970). 
The Yale Law Journal

instances in which the most important interests of resident aliens have been abridged without so much as an inquiry as to the existence of reasonable governmental justification. In light of the equivalency in duties and obligations between citizens and resident aliens, and in light of Schneider $v$. Rusk, the policy justifications on which the volume rests are not viable. The courts should close it, and begin to apply normal standards of constitutional adjudication in naturalization and deportation cases. In doing so, they would necessarily invalidate substantial portions of the current naturalization statute and strike down the reported administrative abuses which the doctrine of unfettered power has fostered. 